\title{
YÜKSEK ADALET DİVANININ GEÇMIŞE ETKİLİ ŞEKİLDE YÜRÜRLÜKTEN KALDIRILMASI -7248 Sayılı Kanun Hakkında Bir Değerlendirme-
}

\author{
Retrospective Abrogation of the High Council of Justice \\ -An Analysis Concerning the Law No. 7248-
}

\section{Emre AKBULUT ${ }^{*}$ - M. Esra YARALI ${ }^{* *}$ - Ömer Faruk ÖZDEMİR ${ }^{* * *}$}

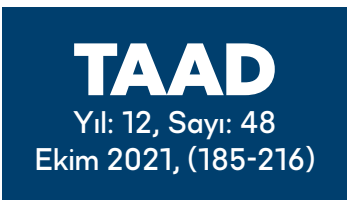

\section{Makale Bilgisi}

Geliş Tarihi : 01.09.2021

Kabul Tarihi : 14.09.2021

Makale Türü: Araștırma

\section{$\underline{\text { Article Info }}$}

Received Date: 01.09.2021

Accepted Date: 14.09.2021

Article Type : Research

\section{ÖZET}

Türkiye Büyük Millet Meclisi yakın dönemde kabul ettiği 7248 sayılı Kanun ile 27 Mayss 1960 tarihli askerî darbeden sonra kurulan Yüksek Adalet Divanı'nın hukuki dayanağını geçmişe etkili şekilde yürürlükten kaldırmıştır. Türkiye'de demokratik hayata geçilmesinden sonra icra edilen ilk askerî darbenin en önemli kurumlarından birini kurulduğu tarihten geçerli olacak şekilde yürürlükten kaldıran bu sıra dışı kanun, özellikle öğretide çeşitli eleştirilere maruz kalmıştır. Bu bağlamda, Yüksek Adalet Divanı'nın bir yargı organı olduğu kabulünden hareketle, 7248 sayılı Kanun'un Anayasa'ya ve erkler ayrılığı prensibine aykırı şekilde mahkeme kararlarını geriye dönük olarak hükümsüz hale getirdiği ileri sürülmüştür. Yine 7248 sayılı Kanun'un parlamentodaki görüşmeleri esnasında anılan kanun, askerî darbeler ve hakkaniyete aykırı yargılamalar arasında seçici davranmakla ve ayrım yapmakla itham edilmiştir. Bu çerçevede çalışmada 7248 sayılı Kanun'a yöneltilen bir kısım eleştiriler ele alınarak, adı geçen kanunun erkler ayrılığı prensibine ve Anayasa'ya aykırı olup olmadığı, hukuka aykırı yargılamalar arasında haksız bir ayrım yapıp yapmadığı ve bu kanunla ulaşılmak istenilen amacin alternatif başka yöntemlerle temin edilebilip edilemeyeceği sorularına yanıt aranmaktadır.

Anahtar Kelimeler: 27 Mayıs 1960 tarihli askerî darbe; Yüksek Adalet Divanı; 7248 sayılı Kanun; doğal hâkim ilkesi; milli egemenlik prensibi; yargı kararlarının yasama tarafından etkisiz kılınması; geçiş dönemi adaleti

\begin{abstract}
Recently, with the Law no.7248, the Grand National Assembly of Turkey retrospectively abrogated the legal basis of the High Council of Justice which had been established after the military coup of 27 May 1960. This a typical law which retrospectively
\end{abstract}

Bu makale Etik Kurul İznine tabi değildir.

* Dr., Hâkim, Türkiye Büyük Millet Meclisi, dr.emreakbulut@gmail.com, https://orcid. org/0000-0002-7031-4166.

** Yasama Uzman Yardımcısı, Türkiye Büyük Millet Meclisi, esrayarali@gmail.com, https:// orcid.org/0000-0003-0218-8230.

*** Türkiye Büyük Millet Meclisi, omerfaruk.ozdemir@tbmm.gov.tr, https://orcid.org/00000002-4779-2418. 
IIIIIIIIII!

abrogated one of the most significant institutions of the first military coup following transition to democracy in Turkey as from the date of that institution's foundation, has attracted varied criticisms especially in the doctrine. In this context, departing from the assumption that the High Council of Justice was a judicial body, it has been claimed that the Law no. 7248 retrospectively overruled the court decisions contrary to the Constitution and the principle of separation of powers. Furthermore, the Law no. 7248 has been accused of being selective and of discriminating between different military coups and unfair trials during the parliamentary discussions. In this framework in the study, considering several criticisms made for the Law no.7248, answers will be sought to the questions of whether aforementioned law has been contrary to the principle of separation of powers and to the constitution, whether it has made unjust discrimination between unlawful trials and whether the aim of this law can also be achieved by any other alternative methods.

Keywords: The military coup of 27 May 1960; the High Council of Justice; the Law no.7248; the principle of natural justice; the principle of national sovereignty; making court decisions void by the legislature; transitional justice

\section{GİRIŞ}

1 Temmuz 2020 tarihli ve 31172 sayılı Resmi Gazete'de' yayımlanarak yürürlüğe giren 7248 sayılı Kanun, Türk Hukuk Tarihinde bir benzerine rastlanmayan sıra dışı bir yasal düzenlemedir. Tam adı "1924 Tarih ve 491 Sayılı Teşkilâtı Esasiye Kanununun Bazı Hükümlerinin Kaldırılması ve Bazı Hükümlerinin Değiştirilmesi Hakkında Geçici Kanunun Bazı Hükümlerinin Yürürlükten Kaldırılması ve Neden Olunan Mağduriyetlerin Giderilmesi Hakkında Kanun" olan bu kanunla, 27 May1s 1960 askerî darbesinden sonra yürürlüğe konulan 1 sayılı Kanun'un bazı hukuki sonuçları hukuk âleminden kaldırılmak istenmiştir. Bu çerçevede 7248 sayılı Kanun ile 12.06.1960 tarihli ve 1 sayılı Kanun'un Yüksek Adalet Divanı ile Yüksek Soruşturma Kurulu'nu kuran 6'ncı maddesi ve 1924 Anayasası'nın müsadere yasağına ilişkin hükmünü bazı bireyler açısından yürürlükten kaldıran 24'üncü maddesinin ikinci fikrası geçmişe etkili şekilde yürürlükten kaldırılmıştır. Yine aynı kanunla Yüksek Soruşturma Kurulu ile Yüksek Adalet Divanı'nın soruşturma ve kovuşturma işlemlerine maruz kalanların uğradıkları manevî zararların Devlet tarafından karşılanmasına ilişkin usul ve esaslar belirlenmiştir.

Bir askerî darbe sonrasında darbe ideolojisini cebren hâkim kılmak için kurulan ve yargısal yetkiler kullanan bir organın hukuki dayanağını geçmişe etkili şekilde kaldıran 7248 sayılı Kanun'un siyasi açıdan taşıdığı önem tartışmasızdır. Ancak 7248 sayılı Kanun'un doğurduğu hukuki sonuçlar, öğretide bir takım tartışmaları beraberinde getirmiştir. İlk olarak Kemal Gözler konu hakkında bir makale kaleme alarak, 7248 sayılı Kanun'un zaten yürürlükte olmayan 1 sayılı Kanun'un bazı maddelerini yürürlükten kaldırarak mantık dışı bir iş yaptığını, ayrıca bunu Anayasa değişikliğine ilişkin kurallara uymadan, adi kanunlar için öngörülen usulle gerçekleştirdiğini ve geçmişe etkili şekilde düzenlenen yürürlük maddesiyle hukuk devleti ilkesini

1 Temmuz 2020 Tarihli ve 31172 Sayılı Resmi Gazete. 
ihlal ettiğini belirtmiştir². Yine Ersan Şen de 7248 sayılı Kanun hakkındaki makalesinde söz konusu kanunun kuvvetler ayrılığ prensibi ile Anayasa'nın 138 'inci maddesinin dördüncü fikrasına aykırı olduğunu ve Yüksek Adalet Divanı kararlarının ancak yargılamanın yenilenmesi yoluyla ortadan kaldırılabileceğini savunmuştur³ .

7248 sayılı Kanun'a yöneltilen eleştiriler öğreti ile sınırlı kalmamıştır. Her ne kadar Türkiye Büyük Millet Meclisi'nde (TBMM) grubu bulunan siyasi partiler 7248 sayılı Kanun'un yasalaşmasına yönelik bir itiraz ileri sürmemişlerse de, kanunun Meclisteki görüşmeleri esnasında askerî darbelerden doğan mağduriyetler giderilirken darbeler arasında ayrım yapılmaması ve 12 Mart 1971, 12 Eylül 1980 müdahalelerinden sonra yürütülen yargılamalar sonucunda verilen kararların da hükümsüz kılınması gerektiği ifade edilmiştir".

Diğer taraftan öğretide kanun teklifine ilk imzayı atan milletvekili sıfatını da taşıyan TBMM Başkanı Mustafa Şentop, 7248 sayılı Kanun'a getirilen eleştirilerden bir kısmına cevap veren bir makale kaleme almış ve çalışmasında, 1 sayılı Kanun'un hukuki niteliği, 2020 yılı itibariyle yürürlükte olup olmadığı 1 sayılı Kanun'un yürürlükten kaldırılması için bir Anayasa değişikliği kanununa gerek olup olmadığı ve 7248 sayılı Kanun'un geçmişe yürütülmesinin hukuk devleti ilkesine aykırı olarak nitelendirilip nitelendirilemeyeceği hususlarını incelemiştir ${ }^{5}$.

7248 sayılı Kanun'un ve bu kanunla bazı maddeleri yürürlükten kaldırılan 12.06.1960 tarihli ve 1 sayılı Kanun'un siyasi ve hukuki tarihimiz açısından taşıdığ

Kemal Gözler, "Yürürlükte Olmayan Bir Kanun Yürürlükten Kaldırılabilir Mi? 23 Haziran 2020 Tarih ve 7248 Sayılı Kanun Hakkında Eleştiriler" (Türk Anayasa Hukuku Sitesi, 25.06.2020) www.anayasa.gen.tr/7248-sayili-kanun.htm Erişim tarihi: 6 Mayıs 2021

3 Ersan Şen, "Yüksek Adalet Divanı'nı Kaldıran 7248 Sayılı Kanunun Değerlendirilmesi" (Hukuki Haber, 27.06.2020) https://www.hukukihaber.net/amp/yuksek-adalet-divaninikaldiran-7248-sayili-kanunun-degerlendirilmesi-makale,8045.html Erişim tarihi: 6 Mayıs 2021

4 bkz. 7248 sayılı Kanun'un görüşüldüğü 17.06.2020 tarihli TBMM Anayasa Komisyonu ve 23 Haziran 2020 tarihli TBMM Genel Kurul tutanakları ve kanun teklifine ilişkin 218 sıra sayılı Anayasa Komisyonu Raporu. TBMM Anayasa Komisyonu Tutanak Dergisi, D.27, Y.3, 17/6/2020; TBMM Genel Kurul Tutanağ1, D.27, Y.3, B.103, 23/6/2020, https://www.tbmm.gov.tr/develop/owa/Tutanak_B_SD.birlesim_ baslangic?P4=23465\&P5=H\&PAGE1=1\&PAGE2=76 Erişim tarihi: 5 Mayıs 2021

1924 Tarih ve 491 Sayılı Teşkilatı Esasiye Kanununun Bazı Hükümlerinin Kaldırılması ve Bazı Hükümlerinin Değiştirilmesi Hakkında Geçici Kanunun Bazı Maddelerinin Yürürlükten Kaldırılmasi ve Neden Olunan Mağduriyetlerin Giderilmesi Hakkında Kanun Teklifi (2/2952) ve Anayasa Komisyonu Raporu, Sira Sayıs1: 218 (D.27, Y.3, B.103, 23/6/2020'ye eklidir). https://www.tbmm.gov.tr/sirasayi/donem27/yil01/ss218.pdf Erişim tarihi: 5 May1s 2021

5 Mustafa Şentop, Bir Kanunun Tahlili: 7248 Sayılı Kanun Nedir, Ne Değildir?”, (2020) (42), Yasama Dergisi, s.97 vd. 
IIIIIIIIII!

dikkatle durulmasını gerektirmektedir. Öğretide Şentop tarafından 7248 sayılı Kanun'a yöneltilen eleştirilerin bir kısmı ${ }^{6}$ hakkında kapsamlı değerlendirmeler yapılmasına karşın, kanunun yarg1 kararlarını hükümsüz hale getirmesi sebebiyle erkler ayrılığı prensibine ve Anayasa'ya aykırı olduğu, ayrıca darbelerden sonra yürütülen hukuka aykırı yargılamalar arasında haksız bir ayrım yaparak sadece Yüksek Adalet Divanı ile ilgili hükümler içerdiği hususlarında ileri sürülen eleştiriler öğretide etraflıca incelenmemiştir. $\mathrm{Bu}$ bağlamda çalışmada, 7248 sayılı Kanun'a ilişkin yasama belgeleri ile kanun hakkında öğretide ve TBMM'de dile getirilen eleştiri ve değerlendirmelerden yola çıkılarak, adı geçen kanunun Anayasa'ya aykırı olup olmadığı, hukuka aykırı darbe yargılamaları arasında haksız bir ayrım yapıp yapmadığı ve kanunla ulaşılmak istenilen amacın yargılamanın yenilenmesi gibi başka yöntemlerle temin edilebilip edilemeyeceği sorularına yanıt aranacaktır. $\mathrm{Bu}$ amaçla öncelikle TBMM'nin Yüksek Adalet Divanını hukuken ne şekilde nitelediği ve bu nitelemenin kabul edilebilirliği incelenecek, akabinde 7248 sayılı Kanun sırasıyla yargı kararlarının etkisizleştirilmesi, alternatif bir hukuki yöntem olarak yargılamanın yenilenmesi kurumu, uluslararası insan hakları hukukunun 'geçiş dönemi adaleti' müessesesi ve kapsamı itibariyle 'darbeler ve hukuksuz yargılamalar arasında ayrımcılık yaptı̆̆ı' iddiası çerçevesinde ele alınacaktır.

\section{A. KANUN KOYUCUNUN NAZARINDA YÜKSEK ADALET DIVANI}

7248 sayılı Kanun'a öğretide getirilen önemli eleştirilerden birisi “ $b u$ kanunla mahkeme kararlarının sonradan, geriye etkili şekilde hükümsüz kllındiğg ve bunun erkler ayrılı̆̆ prensibi ile Anayasa'nın 138 'inci maddesine aykırı olduğu" eleştirisidir7. Gerçekten Anayasa'nın 138'inci maddesinin dördüncü fikrasında "Yasama ve yürütme organlart ile idare, mahkeme kararlarina uymak zorundadır; bu organlar ve idare, mahkeme kararlarinı hiçbir suretle değiştiremez ve bunların yerine getirilmesini geciktiremez"

6 Şentop makalesinde, "çalışmanın kapsamını çok fazla genişletmemek için 7248 sayılı Kanun'un esası hakkında ileri sürülen eleştirilere çalışmada değinilmediğini” ifade etmektedir. Şentop, s.101.

7 bkz. Şen, agm. Şen makalesinde, yargı kararlarının ne şekilde bozulup kaldırılabileceğine dair kanun yollarının ve bunlara ilişkin kuralların 4/12/2004 tarihli ve 5271 sayılı Ceza Muhakemesi Kanunu'nun 260 ve devamı maddelerinde sayıldığını, bir yargı kararının ancak anılan maddelerde gösterilen yol ve yöntemlerle kaldırılabileceğini, özellikle Anayasa'nın mahkeme kararlarının yasama ve yürütme organları ile idare tarafindan hiçbir suretle değiştirilemeyeceğine ilişkin 138 'inci maddesinin dördüncü fikrası uyarınca kuruluşu ve yargılama usulleri ile ilgili tüm hukuka aykırılıklara rağmen verdiği kararlar yargı kararı sayılan Yüksek Adalet Divanı kararlarının kanun düzenlemesi ile kaldırılamayacağını öne sürmektedir. 
hükmü yer almakta olup; 7248 sayılı Kanun'un hukuki dayanağını geçmişe dönük olarak ortadan kaldırdığı Yüksek Adalet Divanı'nın bir mahkeme (yarg1 organı) olarak kabul edilmesi durumunda, söz konusu kanunla Anayasa'nın 138'inci maddesine aykırı şekilde mahkeme kararlarının etkisizleştirildiği belirtilebilecektir.

Ancak 7248 sayılı Kanun'a ilişkin yasama belgeleri incelendiğinde, bu kanunu kabul eden TBMM'nin yani kanun koyucunun, Yüksek Adalet Divanı'nı gerçek anlamda bir 'mahkeme' veya 'yargı organı', Yüksek Adalet Divanı kararlarını da 'yargı kararı' olarak nitelendirmediği görülmektedir. Bunun ilk işaretlerini, kanun teklifinin genel gerekçesinde Yüksek Adalet Divanı kararları hakkında yer verilen "şeklen yargı kararı niteliği taşımakla birlikte esasen millet iradesini kaba kuvvetle gasp eden gücün siyasi arzularının maskesi niteliğinde olan bu kararlar" şeklindeki değerlendirmede gözlemlemek mümkündür8.

7248 sayılı Kanun'a esas teşkil eden teklifin Anayasa Komisyonu'ndaki görüşmelerinde ise bu nokta çok daha açık biçimde ortaya konulmuştur. Buna göre 7248 sayılı Kanun'a ilişkin teklifin kabulüne dair 218 sıra sayılı Anayasa Komisyonu Raporu'nda “Milli Birlik Komitesi (MBK), yasama, yürütme ve yargı organlarını hiçe saymış, millet iradesinin meşru temsilcisi olan parlamentonun yetkilerinin yanında, devletin yürütme ve yargı erklerini ve bunların sahip olduğu bütün hak ve yetkileri de gasbederek kendi uhdesinde toplamıştır. MBK kabul ettiği ilk kanunla söz konusu meşru organların yerine yeni yapılar öngörmüştür. ... Yüksek Adalet Divanı adlı sözde mahkemede toplum tarafindan hiçbir zaman kabul edilmeyen yargılamalar yapılmış, o dönem iktidarda bulunanların mallarına el konulmuş, insanlar mă̆dur edilmiş ve hukuksuz bir şekilde idam kararları verilmiştir. Türkiye Büyük Millet Meclisi olarak siyasi tarihimizde kara bir leke olan bu yargilamalart yapan sözde mahkemenin kuruluşunu düzenleyen 1 sayıl Kanunun 6'ncı maddesi yürürlükten kaldırllarak mevzuatımızın darbe kalıntılarından temizlenmesi son derece önemlidir. ... geçmişe etkili bir şekilde kurulmuş olan 'Yüksek Adalet Divanı' adlı bu sözde mahkemenin yine geçmişe etkili olacak şekilde yürürlükten kaldırılması amaçlanmıştı" "9 ifadelerine yer verilerek, Yüksek Adalet Divanı ısrarlı bir şekilde "sözde mahkeme" olarak tanımlanmıştır.

\footnotetext{
2/2952 sayılı, 1924 Tarih ve 491 Sayılı Teşkilatı Esasiye Kanununun Bazı Hükümlerinin Kaldırılması ve Bazı Hükümlerinin Değiştirilmesi Hakkında Geçici Kanunun Bazı Maddelerinin Yürürlükten Kaldırılması ve Neden Olunan Mağduriyetlerin Giderilmesi Hakkında Kanun Teklifi. https://www2.tbmm.gov.tr/d27/2/2-2952.pdf Erişim tarihi: 5 Mayis 2021

91924 Tarih ve 491 Sayılı Teşkilatı Esasiye Kanununun Bazı Hükümlerinin Kaldırılması ve Bazı Hükümlerinin Değiştirilmesi Hakkında Geçici Kanunun Bazı Maddelerinin Yürürlükten Kaldırllması ve Neden Olunan Mağduriyetlerin Giderilmesi Hakkında Kanun Teklifi (2/2952) ve Anayasa Komisyonu Raporu, Sira Say1s1: 218 (D.27, Y.3, B.103, 23/6/2020'ye eklidir). https://www.tbmm.gov.tr/sirasayi/donem27/yil01/ss218.pdf Erişim tarihi: 6 May1s 2021
} 
IIIIIIIIIII

Anayasa Komisyonu'nda gerçekleştirilen görüşmelerde benzer hususlar milletvekilleri tarafindan da dile getirilmiştir. $\mathrm{Bu}$ çerçevede komisyon görüşmelerinde, örneğin,

- Afyonkarahisar Milletvekili Ali Özkaya, “...yalnızca bir yönetim organına karşı, kişilere karşı onların tüm suçları için fiiller işlendikten sonra oluşturulan bir soruşturma komisyonu ve bu soruşturma komisyonundan sonra yargilama, sözde mahkeme adı altında Yüksek Adalet Divanı kuruldu ... Bu mahkeme sözde bir mahkeme de olsa ve bu mahkemeyi biz tanımasak da yargının sonucunu yasamanın bir fiiliyle, tasarrufuyla ortadan kaldırmayı yargı hayatımız açısından, devlet hayatımız açısından uygun görmediğimiz için özellikle mahkemenin sonuçlarını yok saymıyoruz, buna özel bir dikkat ediyoruz. Çünkü yasama, yürütme ve yargının ayrı olması için ... Biz bu mahkemenin kuruluşuna dair hükümleri kaldırlyoruz ve diyoruz ki: 'Seni mahkeme ve yargı olarak hiç tanımıyoruz' ...",

- Isparta Milletvekili Süreyya Sadi Bilgiç, "Milli Birlik Komitesi ... sözde bir mahkeme kurmuş ve belirli kişiler hakkinda bu mahkeme eliyle yargl yetkisini kullanmıştır ... o dönemin yürürlükteki kanunlarını ve anayasasını çiğneyerek kendi darbe hukukların yaratmak yoluna gitmişler ve siyasi ihtiraslarının sevkiyle, Demokrat Partiden ve onun temsilcilerinden intikam almak için kendi arzularl doğrultusunda kararlar verecek sözde bir mahkeme kurmuşlardır ... bu kanun teklifinden muradımız ... Yassıada'daki düzmece mahkeme tarafindan yargılanan ve hüküm giyen bütün sanıkların çeşitli suçlardan mahkûm oldukları yönündeki var olan şekli gerçekliği değiştirmek(tir) ... teklifle öngörülen de zaten geçmişe etkili bir șekilde kurulmuş olan 'Divan' adlı bu sözde mahkemenin yine geçmişe etkili olacak şekilde yürürlükten kaldırlmasından ibarettir ... kanaatimizce, Yüksek Adalet Divanı, aldı̆̆ kararlarında münferit hukuksuzluklar ya da haksızlıklar sebebiyle değil, bizzat kuruluşunda hiçbir meşru hukuki dayanağg olmadiğından evrensel anlamda bir mahkeme olarak da kabul edilemeyecek bir yapudır ...",

- Tokat Milletvekili Özlem Zengin, “... bakttğınız üzere görüyorsunuz sadece bir grup insanı yargılamak üzere, onlar görevlerini ifa ederken suç olmayan konularla ilgili olarak oluşturulan bir mahkemeden biz bahsediyoruz. Aslinda buna 'mahkeme'de demiyoruz 'sözde mahkeme' diyoruz ... biz bir mahkeme olarak kabul etmiyoruz, onları bir sözde mahkeme olarak görüyoruz ... adına da 'mahkeme' diyememişlerdir farkındaysanız, 'Yüksek Adalet Divanı' denilmiştir, kendi kendilerine de 'mahkeme'bile diyememişlerdir ...",

- Manisa Milletvekili Özgür Özel, “... darbecilerin kendilerince ortaya çıkardıkları, aslında yok hükmünde olan bu yapının varsa akıllarda bir tereddüt bırakmaksızın ortadan kaldıracak bir yasama faaliyetini doğru buluyoruz, önemli buluyoruz ama bununla ilgili teknik eleştiriler, katkllar olabilir ...", 
- Sakarya Milletvekili Muhammed Levent Bülbül, “... bugün görüşmekte olduğumuz kanun teklifiyle en azından 'Yüksek Adalet Divanı' olarak ifade edilen bu düzmece mahkemenin meşruiyet kaynağl olan ve yasama tarafindan çıkarılmış olan bu kanun düzenlemesinin ilgili maddelerinin yürürlükten kaldırllmaslyla bu noktada en azından meşruiyeti yönünden bir klsım mahzurlar telafi edilmeye, giderilmeye çalışılmaktadır."

- Mersin Milletvekili Zeynep Gül Yılmaz, “... evrensel hukuk kurallarına aykırl olarak kurulan, anayasal zemine oturmayan, masumiyet karinesini ve yasama sorumsuzluğunu da ayaklar altına alan, millî iradeyi ortadan kaldirarak millî iradeyi de gasbeden, demokrasi ve hukuk garabeti sözde Yüksek Adalet Divanının kararlarını hükümsüz hâle getirecek bu kanun teklifini çok önemli ve klymetli buluyorum",

- İstanbul Milletvekili Ravza Kavakçı Kan, “... bu çirkin, sözde mahkemelerin kurulduğu, insanların ruhlarının, geleceklerinin, bir milletin ümidinin katledildiği o Yassıada ..." ve

- Mersin Milletvekili Ali Mahir Başarır, “ ... Yüksek Adalet Divanının bu vermiş olduğu kararlar ne kadar hukuksuzsa ne kadar zalimse ne kadar bizim için yok hükmündeyse ..." şeklindeki ifadeleriyle Yüksek Adalet Divanı'nı bugün genel kabul gören anlamıla bir mahkeme olarak nitelendirmediklerini, dolayısıyla söz konusu divanın kararlarını da yargı kararı olarak kabul etmediklerini ifade etmişlerdir ${ }^{10}$.

Son olarak benzer mülahazalar kanunun TBMM Genel Kurulu'nda yürütülen görüşmeleri esnasında da dile getirilmiştir. Bu kapsamda örnek olarak, TBMM Genel Kurulu'nun 23 Haziran 2020 tarihli 103'üncü birleşiminde Yüksek Adalet Divanıhakkında İstanbul Milletvekili Feti Yıldız, "Yassıada yargılamaları âdeta bir tiyatro şeklinde geçmis ve genellikle İstanbul'dan İstanbul sosyetesi ve bazı bürokratların eşleri, birbirinden şık giyimli bürokrat eşleri sabah Fenerbahçe vapuruna binerek bir tiyatro seyretmeye gitmişler, şen şakrak olarak da geri dönmüşlerdir çünkü yapılan bir yargılama değildir"; Ankara Milletvekili Murat Emir, "elbette Yüksek Adalet Divanı bir mahkeme değildi, tabii hâkim ilkesine aykırı kuruldu ve dolaylsiyla da onun kararların yok saymak bu Meclis için bir onurdur"; İstanbul Milletvekili Yunus Emre, "27 Mayıs darbesi sonrasında yapılan yargılamalar bir yargılama değildir, bugünkü anlamıyla, uluslararası anlamıyla bir işkencedir" değerlendirmelerinde bulunmuştur. Yine birleşimi yöneten TBMM Başkanvekili Süreyya Sadi Bilgiç, 7248 sayılı Kanun olarak yasalaşan teklifin görüşülmeye başlandığı oturumun hemen başında Yüksek Adalet Divanı hakkında "sahte ve sözde mahkeme" nitelemesi yaparak görüşmeleri başlatmıştır ${ }^{11}$.

10 TBMM Anayasa Komisyonu Tutanak Dergisi D:27, Y:3, 17/6/2020.

11 TBMMGenelKurulTutanağ1,D.27,Y.3,B.103,23/6/2020.https://www.tbmm.gov.tr/develop/ owa/Tutanak_B_SD.birlesim_baslangic?P4=23465\&P5=H\&PAGE1=1\&PAGE2 $=76$ Erişim tarihi: $\overline{6}$ Mayıs 2021 
IIIIIIIIII!

Görüleceği üzere TBMM üyeleri, gerek kanun teklifi metninde ve gerekse teklifin Komisyon ile Genel Kurul görüşmelerinde Yüksek Adalet Divanı'nın gerçek bir mahkeme, yürüttüğü faaliyetin de gerçek bir yargılama olmadığını 1srarla vurgulamışlardır. Daha önemlisi bu yöndeki müteaddit tespitler TBMM'de temsil edilen farklı siyasi parti gruplarının temsilcilerince yapılmış ve bu yöndeki onlarca değerlendirmeye TBMM bünyesinde herhangi bir itiraz yöneltilmemiştir. Bu veriler ışığında, kanun koyucunun nazarında Yüksek Adalet Divanı'nın evrensel anlamda ve özellikle Anayasa'nın 138'inci maddesinde ifadesini bulan şekliyle bir mahkeme olmadığ 1 , kanun koyucunun anılan divanı bir "sözde mahkeme" olarak kabul ettiği belirtilebilecektir.

\section{B. YÜKSEK ADALET DIVANINI MAHKEME KABUL ETMEYEN KANUN KOYUCUNUN HAKLILIĞI SORUNU}

Kanun koyucunun, 27 Mayıs 1960 tarihli askerî darbe sonrasinda kurulan Yüksek Adalet Divanı'nın bir mahkeme olmadığı düşüncesinden hareketle 7248 sayılı Kanun'u kabul ettiğine yukarıda değinmiştik. Bu durumda yani Yüksek Adalet Divanı bir mahkeme ya da bir yargı organı olarak kabul edilmediği takdirde 7248 sayılı Kanun'la erkler ayrılığ 1 prensibine ve Anayasa'nın 138 'inci maddesine aykırı bir yasama faaliyeti yürütüldüğü eleştirisi ${ }^{12}$ temelsiz kalacağından, kanun koyucunun bu değerlendirmesinin haklı olup olmadığ 1 üzerinde durulması gerekmektedir.

7248 sayılı Kanun'la kuruluşunun hukuki dayanağı geçmişe etkili şekilde yürürlükten kaldırılan Yüksek Adalet Divan1, 12.06.1960 tarihli ve 1 sayılı Kanun'un 6'ncı maddesiyle kurulmuştur. Bu madde özetle aşağıdaki hükümleri içermektedir:

"Sâkıt Reisicumhur ile Başvekil ve Vekilleri ve eski iktidar mebuslarını ve bunların suçlarına iştirak edenleri yargılamak üzere bir 'Yüksek Adalet Divanı' kurulur. Yüksek Adalet Divanı, Adlî, İdari ve Askerî kazaya mensup Hâkimler arasindan, Bakanlar Kurulunun teklifi üzerine, Millî Birlik Komitesince seçilecek bir Başkan, sekiz aslî ve altı yedek üyeden kurulur. Sanıkların sorumluluklarını araşstırmak ve haklarında son tahkikat açılarak Yüksek Adalet Divanına verilmeleri gerekip gerekmediğine karar vermek üzere bir 'Yüksek Soruşturma Kurulu' teşkil olunur. Yüksek Soruşturma Kurulu, Bakanlar Kurulunun teklifi üzerine Millî Birlik Komitesince seçilecek bir Başkan ile otuz üyeden kurulur. Bu Kurulun teşkilâtı ve çalışma usulü özel kanunla belirtilir. ... Yargılanmaları, 1924 tarihli Teşkilâtı Esasiye Kanununa göre Divanı Âliye ait bulunan şahıslar hakkında soruşturma ve yargılama yetkisi dahi Yüksek Adalet Divanı ve Yüksek Soruşturma Kurulu tarafindan kullanılır."13

12 bkz. Şen, agm.

13 bkz. 14 Haziran 1960 Tarihli ve 10525 Sayılı Resmi Gazete. 
Yüksek Adalet Divanı ve bu divan önünde iddia makamı görevini üstlenecek olan Yüksek Soruşturma Kurulu, 27 Mayıs askerî darbesini icra eden Milli Birlik Komitesi tarafindan 12 Haziran 1960 tarihinde kabul edilen ve 14 Haziran 1960 tarihli Resmi Gazete'de yayımlanan 1 sayılı Kanun'la kurulmuş olmasına rağmen, 27 Mayıs 1960 ilâ 12 Haziran 1960 tarihleri arasında gerçekleştirilen yakalama, gözaltına alma ve tutuklama işlemlerini şeklen hukuka uygun kılabilmek için aynı Kanun'un 26'ncı maddesinde yer alan hükümle 1 sayılı Kanun'un yürürlük tarihi geriye çekilmiş ve böylece Yüksek Adalet Divanı ile Yüksek Soruşturma Kurulu geçmişe dönük şekilde, 27 Mayıs 1960 tarihinden itibaren hukuki varlık kazanmışlardır.

Yüksek Adalet Divanı'nın normatif alt yapısı aktarıldıktan sonra bu başlık altında ilk olarak belirtilmelidir ki, bir mahkemenin verdiği kararların hukuka aykırı olması, bu hukuka aykırılık Anayasa' ya ve hatta hukukun genel ilkelerine aykırılık şeklinde tezahür etse dahi, o mahkemeyi "mahkeme", kararlarını da "yargı kararı" olmaktan çıkarmayacaktır. Bununla birlikte 7248 sayılı Kanun'a konu oluşturan Yüksek Adalet Divanı açısından ortaya çıkan ve önemli kısmı söz konusu kanunun yasalaşma sürecinde TBMM'de dile getirilen ağır hukuka aykırılıkların sadece divanın verdiği kararlara ilişkin olmadığı; bu aykırılıkların bizzat divanın varlığına (hukuk âleminde var olmasına) ilişkin bulunduğu görülmektedir.

Bu çerçevede Yüksek Adalet Divanı'nın varlığına ve dolayısıyla kararlarının bir kısmına değil istisnasız tüm karar ve işlemlerine sirayet eden hukuka aykırılıkların kısaca aşağıdaki şekilde özetlenmesi mümkündür:

i. Doğal (Tabiî) Hâkim İlkesine Aykırılık: "Kanunî hâkim" yahut "olağan hâkim" ilkesi olarak da isimlendirilen doğal hâkim ilkesi, belirli bir uyuşmazlığ 1 karara bağlayacak olan hâkim veya mahkemenin, o uyuşmazlığın doğmasından önce belirlenmesini (kurulmasını ve yetkilendirilmesini) gerekli kılar ${ }^{14}$. Doğal hâkim ilkesinin amacı bir uyuşmazlığ 1 karara bağlayacak yargı organını yasama veya yürütmenin kişiye yahut olaya özgü şekilde belirlemesini önlemektirir ${ }^{15}$. Buna göre belirli bir olaydan sonra ve sadece belirli kişileri yargılamak üzere bir merci kurulması doğal hâkim ilkesine aykırılık oluşturacaktır.

$\mathrm{Bu}$ bağlamda Yüksek Adalet Divanı, 12.06.1960 tarihli ve 1 sayıl1 Kanun'un 6'ncı maddesinde belirtildiği üzere, "sabık Reisicumhur ile Başvekil ve Vekilleri ve eski iktidar mebuslarını ve bunların suçlarına iştirak edenleri" yani sadece belirli Demokrat Parti mensuplarını, 27 Mayıs 1960 tarihinden önce icra ettikleri eylemler sebebiyle yargılayıp cezalandırmak üzere kurulmuştur.

14 Doğal hâkim ilkesi hakkında detaylı bilgi için bkz. Kemal Gözler, "Sulh Ceza Hâkimlikleri ve Tabiî Hâkim İlkesi: 'Sahur Operasyonu' Hakkında Bir Açıklama”, (Türk Anayasa Hukuku Sitesi, 29.06.2020) <www.anayasa.gen.tr/tabii-hakim.htm > Erişim tarihi: 6 Mayıs 2021 (Yayın Tarihi: 29 Ağustos 2014).

15 Erdener Yurtcan, Ceza Yargılaması Hukuku, (16. Bası, Seçkin Yayıncılık 2019) 133. 
IIIIIIIIII

Öte yandan bu hukuka aykırılık Yüksek Adalet Divanı'nın tüm tasarrufları bakımından geçerlidir. Zira bu divan, darbe öncesi dönemde yönetimde olan söz konusu şahısların 27 Mayıs 1960 tarihinden önceki faaliyetleri dışında başka hiçbir kişi veya eyleme yönelik yargılama tasarrufu icra etmemiştir. Diğer bir ifadeyle kuruluşunun ve varlı̆̆ının doğal hâkim prensibine aykırı olmasının yanı sıra, Yüksek Adalet Divanı'nın (sonradan) doğal hâkim ilkesine aykırılık oluşturmadan yaptığı herhangi bir yargılama tasarrufu da bulunmamaktadır ${ }^{16}$.

Dolayısıyla Yüksek Adalet Divanı'nın hukuk âleminde doğuşunun, varlığının ve istisnasız tüm işlem ve kararlarının, evrensel bir hukuk prensibi olan ve bugün 1982 Anayasası'nın 37'nci maddesinde güvence altına alınan doğal hâkim ilkesine açıkça aykırılık oluşturduğu anlaşılmaktadır.

ii. Kanunsuz Suç Olmaz (nullum crimen sine lege) İlkesine Aykırılık: Kanunilik ilkesi ceza hukukunun temel ilkelerinden biridir $^{17}$. Bu ilke uyarınca herhangi bir fiile suç olma özelliğini veren kanunun onu açıkça suç olarak öngörmüş olması ve yine kanunun onun için tespit ettiği müeyyidenin açıkça cezaî nitelik taşımasıdır. Devletin bireylere keyfi davranmasının önüne geçmeyi amaçlayan bu ilke, icra edildiği tarihte yürürlükte olan kanunların suç saymadığı bir eylem sebebiyle hiç kimsenin yargılanamamasını ve cezalandırılamamasinı gerektirmektedir ${ }^{18}$.

Ancak Yüksek Adalet Divanı'nın faaliyetleri incelendiğinde söz konusu divanın yürüttüğ̈̈ yargılamaların tamamına yakınının bu ilkeye aykırı olduğu; hatta divanın zaten bu ilkeye aykırı yargılamaları yürütmek üzere kurulduğu görülmektedir. Zira Yüksek Adalet Divanı yargılamalarının önemli bölümü

16 Örneğin öğretide Gözler 2014 yılında kurulan sulh ceza hâkimliklerinin doğal hâkim ilkesine aykırı şekilde kurulduğunu ileri sürmüştür. Gözler'in görüşü doğru kabul edilse bile bu hâkimliklerin Gözler'in iddiasına neden olan 2014 yılına ilişkin belirli uyuşmazlıklar dışında, doğal hâkim ilkesi açısından sorun oluşturmadığı kesin olan başka binlerce dosyayı karara bağladıkları tartışmasızdır. bkz. Kemal Gözler, "Sulh Ceza Hâkimlikleri ve Tabiî Hâkim İlkesi: 'Sahur Operasyonu' Hakkında Bir Açıklama”.

17 Nevzat Toroslu, Ceza Hukuku Genel Kısım, (20. Bası, Savaş Yayınevi 2014) 39.

18 Ayhan Önder, Ceza Hukuku Dersleri, (1. Bas1, Filiz Kitabevi 1992), 58. Belirtilmelidir ki, kanunsuz suç ve ceza olmaz ilkesi ile doğal hâkim ilkesinin -tartışmalı da olsa- günümüzde kabul edilen tek istisnası, insanlığa karşı suçlar olarak kabul edilen soykırım ve savaş suçları gibi suçları yargılamak üzere uluslararası ceza mahkemelerinin kurulabilmesi ve bu mahkemelerin, ulusal hukuka göre suç sayılmayan eylemleri geçmişe dönük şekilde yargılayabilmesidir. Ancak bu durumda söz konusu olan, insanlığa karşı suç olduğu uluslararası hukukta genel kabul gören belirli eylemlerin işlenmesinden sonra bu eylemleri yargılamak üzere uluslararası bir mahkeme kurulmasıdır ki bunun, Yüksek Adalet Divanı ile hiçbir şekilde ilgisinin olmadığı açıktır. bkz. BM Uluslararası Hukuk Komisyonu, Nuremberg İlkeleri, 1950, <https://legal.un.org/ilc/texts/instruments/english/draft_articles/ 7_1_1950.pdf > Erişim tarihi:11 Mayıs 2021; Christian Tomuschat, "The Legacy of Nuremberg", Journal of International Criminal Justice, Oxford University Press, (2006) 4, 830-844. 
27 Mayıs 1960 tarihinden önceki Başbakan, bakanlar ile milletvekillerinin TBMM'de kanun kabul ederken ya da Meclis Araştırması Komisyonu kurarken kullandıkları oyun rengine ve yaptıkları konuşmaların içeriğine ilişkindir ${ }^{19}$. Hâlbuki bu oy ve konuşmaların icra edildiği tarihte yürürlükte bulunan en üst norm olan 1924 tarihli Teşkilât-1 Esasiye Kanunu'nun 17'nci maddesi, yasama sorumsuzluğuna ilişkin "Hiçbir mebus meclis dahilindeki rey ve mutasından ve beyanatından ve Meclisteki rey ve mütalaasinin ve beyanatının meclis haricinde irat ve izharından dolayı mesul değildir" hükmünü içermekteydi. $\mathrm{Bu}$ çerçevede darbe öncesi Başbakan, bakan veya milletvekili olan sanıkların eylem tarihinde cezaî mesuliyet gerektirmeyen eylemleri, darbe sonrası bizzat bu amaçla kurulan Yüksek Adalet Divanı'nda icra edilen yargılamalarla suç olarak kabul edilmiş ve 395 kişi $^{20}$ hakkında yasama sorumsuzluğu kapsamındaki eylemleri nedeniyle yargılamalar yapılarak, bazıları hakkında idam da dâhil olmak üzere çeşitli cezalar verilmiştir ${ }^{21}$.

iii. Masumiyet Karinesine Aykirllı: Masumiyet karinesi, hakkında kesinleşmiş bir mahkûmiyet hükmü verilinceye kadar sanıkların masum sayılmalarını (item quilbet presumitur innocens nisi probetur nocens), diğer bir ifadeyle suçlu kabul edilmemelerini gerektiren evrensel hukuk ilkesidir ${ }^{22}$.

Yüksek Adalet Divanı ise, daha karar vermeden ve hatta yargılama faaliyetine başlamadan önce yargılayacağı kişilerin "suçlu" olduğu kabul ve ilan edilen, bu anlamda ne yönde karar vereceği önceden belirli olan bir kuruldur. Yüksek Adalet Divanı açısından masumiyet karinesini zedeleyen ilk husus 1 sayılı Kanunun 6'ncı maddesinde yer alan ve divanın, "düşük Cumhurbaşkanı, Başbakan, bakanlar ile iktidar mensuplarını, ayrıca bunların suçlarına iştirak edenleri" yargılamak üzere kurulduğunu belirten hükmüdür ${ }^{23}$. Zira bu maddenin lafzından, Yüksek Adalet Divanı'nın henüz kuruluş aşamasında yargılayacağ 1 ismen belli kişilerin suçlu kabul edildiği anlaşılmakta ve aynı hükümle, söz konusu suçluların suçlarına iştirak edenleri yargılama yetkisi

19 bkz. Yüksek Adalet Divanı'nın 15.09.1961 tarihli, E.1960/1 sayılı kararı. Yüksek Adalet Divanı Kararlarl, İstanbul - Yassıada, 14 Ekim 1960 - 15 Eylûl 1961, (1. Bas1, Kabalcı Yayınevi 2007) 12-396.

20 Yüksek Adalet Divanı'nda yargılanan toplam kişi sayısı 592'dir. bkz. Yüksek Adalet Divanı Kararları.

21 bkz. Yüksek Adalet Divan1, 1960/1, 15.09.1961.

22 Atilla Tanrıvermiş, Lekelenmeme Hakkı, (1. Bası, Seçkin Yayıncılık 2021) 40.

23 Yine 1 sayıl Kanun'un dibacesinde yer alan "İktidar Partisi idarecileri tarafindan Anayasa'nın çiğnenmesi, Türk Milletinin bütün fert ve insanlık hak ve hürriyetlerinin ve masuniyetlerinin ortadan kaldırılması, muhalefet murakabesi işlemez hale getirilerek tek parti diktatoryası kurulması ..." cümleleri de, Yüksek Adalet Divanı'nda yargılanan kişilerin söz konusu dönemde geçerli olan pozitif hukuk kuralları uyarınca suçlu olduklarının bir başka delilidir. Buna göre Yüksek Adalet Divanı'nın yargıladığı kişilerin tamamı hakkında beraat kararı vermesi gibi bir ihtimal hiçbir zaman mevzubahis değildi; zira aksi durum, 1 sayılı Kanun'un başlangıç kısmı ile 6'ncı maddesine aykırılık oluşturacaktı. 
IIIIIIIIII!

de Yüksek Adalet Divanı'na verilmektedir. Bu durumda 1 sayılı Kanun'un kabul edildiği 12 Haziran 1960 tarihi itibariyle ortada, bizzat kanun maddesine yazılan birden fazla suç ("suçlar") ve bu suçlara iştirak eden kişiler vardır. $\mathrm{Bu}$ çerçevede Yüksek Adalet Divanı'nın daha kurulduğu tarihte peşinen suçlu kabul kişiler hakkında yargılama faaliyeti icra etmek üzere teşekkül ettirildiği ifade edilebilecektir.

Yüksek Adalet Divanı'nın faaliyetleri ile ilgili olarak masumiyet karinesine aykırılık oluşturan ikinci husus, 1960 yılının Ekim ayında basılan ve Yüksek Adalet Divanı celselerini izlemek üzere Yassıada'ya gidenlere dağıtılan "Yassıada Broşürü"dürr24. Bu broşür, divanın işlemlerinin gerçek anlamda yargılama olarak değerlendirilemeyeceğinin kanıtı niteliğindedir. Yassıada'da yargılananların hangi suçları işlediklerini, kararların açıklandığı 15 Eylül 1961 tarihinden ${ }^{25}$ çok önce teker teker sayan bu belge, Yüksek Adalet Divanı'nın hangi amaçla kurulduğunu ve masumiyet karinesinin hiçe sayıldığını gözler önüne sermektedir.

27Mayıs 1960 tarihinitakibenDevletyetkilerinielindebulunduranMilliBirlik Komitesi tarafından bizzat bastırılan ve Yüksek Adalet Divanı yargılamalarını izlemek üzere Yassıada'ya giden kimselere dağıtılan broşürde, divanın bizzat varlığının masumiyet karinesine aykırılık olarak nitelendirilebileceğini gösteren ifadelerden bazıları aşağıdaki gibidir: "YASSIADA'NIN MÂNASI ... Yassıada, devleti, çiftlik kâhyası ve bir mirasyedi gibi idare zihniyetine indirilmiş sembolik bir şamardır. Yassiada, iktidar zevki, memleket sevgisinin, partizan düşüncelerini memleket menfaatlerinin üstünde tutan demagog politikacinın ibret sahnesidir. Yassiada, seçmenlere reylerinin sahipliğini, Milletvekillerine, Mecliste kaldıracağı parmağının şuur ve idrakini sağlamıştır ${ }^{26}$. .. DÜ̈SÜK IKTIDAR MENSUPLARI NEDEN YARGILANMAKTADIR? 1924 tarihli Esas Teşkilât Kanununun bazı hükümlerini kaldıran ve bazı hükümlerini değiştiren Geçici 1 sayılı Kanunun birinci bölümünde de kayıt ve işaret olunduğu üzere, düşük iktidar partisini sevk ve idare edenler, Türk milletinin fert ve insanlik hak ve hürriyetlerini ve masuniyetlerinin temel direği olan Anayasayı işlemez hale getirmişler; milletin umumî arzu ve temayüllerinin bir mâkesi olan matbuatı ve muhalefet murakabesini susturmak ve boğmak suretiyle millet hakimiyeti yerine parti diktatoryasını kurmak hevesine kapılmışlar; bu maksadın temini cümlesinden olarak Büyük Millet Meclisini fiilen bir parti grubu durumuna düşürmüşlerdir ... Milletin masum reyi ile Milletvekili seçilmiş; Vekil, Başvekil ve Reisicumhur olmuş bu adamların büyük ekseriyeti, ne pahasina

24 Yassıada Broşürü, Milli Birlik Komitesi İrtibat Bürosu, Basın Yayın ve Turizm Genel Müdürlüğü, Ekim 1960. Broşürün pdf versiyonu için bkz. http://menadoc.bibliothek.unihalle.de/landau/content/titleinfo/208980 Erişim tarihi: 11 Mayıs 2021

25 bkz. Yüksek Adalet Divan1, 1960/1, 15.09.1961.

26 Yassiada Broşürü, s.21. 
olursa olsun, ikbalde iken keselerini doldurmak, yakın ve uzak akraba ve ahbaplarına doğrudan doğruya veya vasitalt olarak Devlet Hazinesinden menfaatler sağlamak arzu ve gayesinde idiler. Bunun için türlü şekiller ve kombinezonlarla nüfuz ve vazife suiistimalleri yapmak, onlartn hiç endişe etmeden başvurduklart yollard ${ }^{27}$. ... Ceza Kanununun ekseri maddelerini ihlâl etmiş ve suçlu durumdaki iktidar mensuplarının ve yakınlarının sözde şeref ve haysiyetlerini koruma maskesi altında, matbuata çok ağır ve gayri kabili tahammül cezalar koyan kanunları dahi aynı yolla elde etmişs28; ... 27 Mayıs İnkılâbı ile bir anda sukut etmis olan bu iktidar mensupları, başta eski düşük Reisicumhur olmak üzere, Başvekil, Vekiller ve bu düşük iktidarın Milletvekilleri ve onların suçlarına iștirak edenler önümüzdeki günlerde yargılanacaklardır'29. ... Yargılanacaklardır, zira bunlar, Zile'de, Uşak'da, Turgutlu'da ve Kayseri'de Muhalefet Liderini öldürmek için pusu kurmuşlar, muhalefetin, memleketi dolaşma hürriyetini baltalamak ve onlarl ylldırmak için Geyikli ve Yeşilhisar hâdiselerini yaratmışlardır. Zira bunlar: devlet hizmetlerinde sarfedilmek üzere ellerine emanet edilmiş devlet parasını çalmış veya keyiflerinde harcamışlardır. Türlü nüfuz suistimalleriyle kendilerine ve yakınlarına menfaat sağlamışlardır. ..." ${ }_{30}$

Yassıada Broşürü'nde, Yüksek Adalet Divanı'nda yargılananlar hakkında yer verilen ve daha yargılamalar sürerken sanıkları suçlu ilan eden bu genel ifadelerin yanı sıra, divanda yargılanan bazı Devlet adamları hakkında münferiden yer verilen ve masumiyet karinesi ile bağdaşması mümkün olmayan şu ibareler de göze çarpmaktadır: "DÜŞÜK CUMHURBAŞKANI CELÂL BAYAR Anayasanın 41 nci maddesine göre düşük Cumhurbaşkanı Celâl Bayar, Büyük Millet Meclisine karşı hiyaneti vataniye suçundan dolayı mesul bulunmaktadır. ... bu adam bir Devlet Reisi olarak değil bir Parti Başkanı olarak vazife görmüss ve tarafsı bir şahsiyet olarak bulunması icabederken, Demokrat Parti başlıklı bastonunu gülünç bir iftiharla taşıdığı ibretle görülmüştür. Düşük Cumhurbaşkanının Millî Inkılâp Hareketini zaruri kılan fiillerini göz önünde bulunduran Millî Birlik Komitesi kendisinin muhtelif suçları arasında bilhassa Türk Ceza Kanunu'nun 125, 141-3, 146 ve 149 ncu maddelerindeki suçları işlediği neticesine varmış bulunmaktadır. ... düşükk Reisicumhur Celâl Bayar, vatana ihanet suçunu işlemiş ve Millî Birlik Komitesi kendisini vatana ihanet suçundan yargllamak üzere, Yüksek Adalet Divanına sevkini karar altına almış bulunmaktadır ${ }^{31}$... DÜŞÜK BAŞBAKAN ADNAN MENDERES Başbakanın, Bakanlar Kurulu Reisi olarak

\footnotetext{
Yassiada Broşürü, s.22.

Yassıada Broşürü, s.24.

Yassıada Broşürü, s.25.

Yassıada Broşürü, s.26.

31 Yassiada Broşürü, s.28.
} 
IIIIIIIIII!

kabine ve müşterek olarak Mecliste beraber işlediği Anayasaya aykırı fiil ve hareketler ile 15 kişilik Meclis Tahkikat Komisyonu teşkili ve bu komisyonun faaliyetine müteallik olup Türk Ceza Kanununun 146 ncı maddesine mümas bulunan suçları dışında şahsen mesul olduğu suçları da mevcuttur. ..."”

Görüleceği üzere Yüksek Adalet Divanı, sadece bazı hukukî tasarruflarında masumiyet karinesine aykırılık oluşturan münferit uygulamalar bulunan bir organ değil; bilakis, kendisini kuran Milli Birlik Komitesi'nin aleni şekilde dağıttığı bir broşürle peşinen suçlu kabul ve ilan ettiği kişileri, bu suçlardan yargılamak ve cezalandırmak üzere hukuk dünyasında var edilmiş bir kuruldu.

$\mathrm{Bu}$ başlık altında üzerinde durulması gereken bir diğer husus, Yüksek Adalet Divanı'nın varlığının ve icra ettiği yargılamaların, evrensel hukuk prensiplerinin yanı sıra, o tarihte yürürlükte olan Türk pozitif hukukuna da aykırılık oluşturduğudur. Zira Türkiye Cumhuriyeti'nin kuruluş felsefesini yansıtan başlıca ilke olan ve 1960 askerî darbesinin yapıldığı tarihte yürürlükte bulunan 1924 Anayasası'nın (Teşkilât-1 Esasiye Kanunu'nun) 3'üncü maddesinde ${ }^{33}$ düzenlenen "egemenliğin kayltsız şartsı millete ait olduğu" prensibi, 12.06.1960 tarihli ve 1 sayılı Kanun veya daha sonra kabul edilen bir başka kanun ile yürürlükten kaldırılmamıştı. Egemenliğin herhangi bir kayda veya şarta tâbi olmadan, her durumda ve istisnasız şekilde millete ait olduğunu hükme bağlayan söz konusu prensip gereğince, egemenliğin unsurlarından biri olan yarg1 yetkisini kimin kullanacağına da milletin karar vermesi gerektiği açıktır. Üstelik bu, soyut bir temenni ya da olması gereken hukukun (de lege ferenda) ifadesi değil; 1924 Anayasası'nın 3'üncü maddesi uyarınca Yüksek Adalet Divanı'nın kurulduğu ve faaliyet gösterdiği tarihte yürürlükte olan bir pozitif hukuk ilkesidir.

Yüksek Adalet Divanı'nın varlığı ise ne kurulduğu tarihte yürürlükte olan Anayasa'ya ne de millet ya da temsilcileri tarafindan kabul edilen kanunlara dayanmaktaydı. Diğer bir ifadeyle Yüksek Adalet Divanı ile egemenliğin sahibi olan Türk Milleti arasında doğrudan ya da dolaylı herhangi bir bağlantı, bir illiyet rabıtası yoktu. Bu noktada Milli Birlik Komitesi’nin elinde tuttuğu silahlara istinaden kullandığı fiziki ve fiili gücün, Yüksek Adalet Divanı ile millet arasında herhangi bir rabıta sağlamayacağı açıktır. Dolayısıyla Yüksek Adalet Divanı, egemenliğin sahibi olan milletle herhangi bir bağa sahip olmadığı, ondan yetki ve onay almadığ 1 için; kurulduğu tarihte yürürlükte olan "egemenlik kayıtsız şartsız milletindir" kuralına aykırı şekilde teşekkül etmiş bir müessesedir. Böyle bir müessesenin Türk Hukukunda (bugün yürürlükte

32 Yassıada Broşürü, s.28-29.

33 Teşkilâtı Esasiye Kanunu'nun 3. maddesi aşağıdaki biçimdedir: "Madde 3- Hâkimiyet bilâ kaydü şart Milletindir." 
olan Anayasa'nın 138'inci maddesindeki anlamıla) "mahkeme" olarak kabul edilebilmesi mümkün değildir ${ }^{34}$.

Sonuç olarak Yüksek Adalet Divanı bizzat kuruluşu ve varlığı evrensel hukuk kurallarına (doğal hâkim ilkesine) aykırı olan ve evrensel hukuk kurallarına (kanunsuz suç olmaz prensibi ile masumiyet karinesine) aykırı işlemler yapmak ve kararlar vermek üzere teşkil edilen bir organdır. Yine Yüksek Adalet Divanı, 27 Mayıs 1960 tarihli askerî darbeden sonra dahi yürürlükte bulunan bir Anayasa kuralına aykırı şekilde egemenlik yetkileri kullanmak üzere kurulmuştur.

Tüm bu veriler ışığında Yüksek Adalet Divanı'nın, kararlarındaki münferit hukuksuzluklar sebebiyle değil, bizzat daha hukuk dünyasında varlık kazanmasında söz konusu olan esaslı hukuka aykırılıklar sebebiyle gerek evrensel anlamda gerekse Türk Hukuku açısından gerçek bir "mahkeme" olmadığı, ancak yargısal yetkiler kullanan nevi şahsına münhasır (sui generis) bir kurul olduğu; dolayısıyla bugün Yüksek Adalet Divanı'nı gerçek değil sözde bir mahkeme olarak nitelendiren kanun koyucunun bu kabulünde haksız sayılamayacağı belirtilebilecektir.

\section{7248 SAYILI KANUNUN AMACI ve ALTERNATİF BİR YÖNTEM OLARAK YARGILAMANIN YENILENMESI}

7248 sayılı Kanun'u kabul eden kanun koyucunun Yüksek Adalet Divanı'nı bir mahkeme ya da yargı organı olarak nitelendirmediğinin ve bu noktada haksız sayılamayacağının ortaya konulması, söz konusu kanunun yarg1 kararlarını geçersiz kılarak erkler ayrılığı prensibine ve Anayasa'nın 138'inci maddesine aykırılık oluşturduğu eleştirisini önemli ölçüde karşılamaktadır. Bununla birlikte kanun koyucunun, yargısal kararlara müdahale edildiği noktasında tereddüt uyandırabilecek bir yol izlemek yerine, 7248 sayılı Kanun'la ulaşmak istediği amaca başka alternatif yöntemlerle ulaşabilip ulaşamayacağ üzerinde de ayrıca durulması gerekmektedir. Bu kapsamda öğretide kanun koyucunun Yüksek Adalet Divanı'nın varlığına geçmişe etkili şekilde son vermesinin Anayasa'ya aykırı olduğu ileri sürülürken, söz konusu divanın kararlarının ancak yargılamanın yenilenmesi yoluyla ortadan kaldırılabileceği ileri sürülmüştür ${ }^{35}$.

$\mathrm{Bu}$ noktada öncelikle belirtilmelidir ki, 7248 sayılı Kanun'un genel gerekçesinde yer alan "milletten aldığı bir yetki bulunmaksızın yargı erkini

34 Bu noktayı aydınlatması açısından belirtilmelidir ki, eğer Milli Birlik Komitesi hemen yeni Anayasa'yı hazırlayıp halkoyuna sunsa ve Yüksek Adalet Divanı, kanun adıverilen Milli Birlik Komitesi kararı ile değil de milletin oyu ile kabul edilen 1961 Anayasası tarafından kurulsaydı, o takdirde Yüksek Adalet Divanı şüphesiz, egemenlik kayıtsız şartsız milletindir prensibine uygun şekilde teşekkül ettirilmiş olurdu.

35 bkz. Şen, agm. 
IIIIIIIIII!

kullanan Yüksek Adalet Divanı'nın verdiği, doğal hâkim ilkesi başta olmak üzere evrensel hukuk prensiplerine ve o tarihte yürürlükte bulunan Anayasa hükümlerine açıkça aykırılık teşkil eden kararlar ne yazık ki hâlen hukuk sistemimizde varlığını sürdürmektedirler. Şeklen yargı kararı niteliği taşımakla birlikte esasen millet iradesini kaba kuvvetle gasp eden gücün siyasi arzularının maskesi niteliğinde olan bu kararların hukuk âlemimizden silinmesi, Türkiye Cumhuriyeti Devleti'nin temelini oluşturan millî egemenlik, demokrasi, insan hakları ve hukukun üstünlüğ̈̈ ilkelerinin gereği olarak tezahür etmekte ve ülkemiz hukuk tarihinin karanlık bir lekeden arındırılması adına zorunluluk arz etmektedir" ifadelerinden anlaşılacağ 1 üzere söz konusu kanunla amaçlanan husus, Yüksek Adalet Divanı tarafından verilen kararların Türk Hukuku'ndaki mevcudiyetlerine son vermek ve bu kararları hukuk âleminden silmektir. Diğer bir ifadeyle 7248 sayılı Kanun'un, "27 Mayıs 1960 tarihinden önce Cumhurbaşkanı olan Celal Bayar, Başbakan olan Adnan Menderes, bakanlar, milletvekilleri ve diğer kişiler çeşitli suçlardan mahkûm olmuş kişilerdir" ş̧eklindeki hukuki gerçekliği değiştirmeyi, Türk pozitif hukukunda anılan şahısların "mahkûm olmamış" konuma getirilmesini amaçladığı anlaşılmaktadır³.

Bu noktada özel bir kanunla yargılamanın yenilenmesi müessesesi işletilerek Yüksek Adalet Divanı'nın karar verdiği 19 dosyada $^{37}$ yeniden yargılama yapılması ve daha önce verilen mahkûmiyet kararlarının beraat şeklinde değiştirilmesi durumunda da 7248 sayılı Kanun ile izlenilen söz konusu amaca ulaş1labileceği belirtilebilecektir. Ancak bu ihtimal, mantıken Yüksek Adalet Divanı'nın gerçek bir mahkeme, kararlarının da gerçek anlamda meşru birer yarg1 kararı olarak kabul edildiği neticesini -kaçınılmaz olarak- doğuracaktır. Oysa yukarıda da izah edildiği üzere kanun koyucu Yüksek Adalet Divanı'nı gerçek bir mahkeme, kararlarını da yargı kararı olarak nitelendirmediği için, yargılamanın yenilenmesi kanun koyucunun bu yaklaşımının tam tersi bir sonuç doğurarak Yüksek Adalet Divanı'na ve yaptığı yargılamalara hukuki meşruiyet kazandırmış olacaktır ${ }^{38}$. Nitekim bu husus, 7248 sayılı Kanun

36 “... bu kanun teklifinden muradımız, böylesine hukuk dışı bir süreçyürütülerek kurban edilen, başta dönemin Başbakanı Adnan Menderes ve iki Bakanı Hasan Polatkan ve Fatin Rüşü Zorlu olmak üzere, Yasslada'daki düzmece mahkeme tarafindan yargllanan ve hüküm giyen bütün sanıkların çeşitli suçlardan mahkûm oldukları yönündeki var olan şeklî gerçekliği değisstirmek(tir). ..." Isparta Milletvekili Süreyya Sadi Bilgiç'in Anayasa Komisyonu'ndaki açıklamalarından. bkz. https://www.tbmm.gov.tr/develop/owa/komisyon_tutanaklari. goruntule?pTutanakId=2543 Erişim tarihi: 16 Mayıs 2021

37 bkz. Yüksek Adalet Divanı Kararları, İstanbul - Yassıada, 14 Ekim 1960 - 15 Eylûl 1961, s.11.

38 Kanun koyucunun 7248 sayılı Kanun'u kabul ederken izlediği amaç açısından benzer bir sakınca af müessesesi açısından da geçerlidir. Bu kapsamda Yüksek Adalet Divanı tarafından verilen kararlar 15.05.1974 tarihli, 1803 sayılı Kanun ile affedilmiş olsa da; af, 
görüşmelerinde Anayasa Komisyonu'nda da ifade edilmiştir ${ }^{39}$.

Diğer taraftan Yüksek Adalet Divanı kararları ile ilgili olarak yargılamanın yenilenmesi durumunda, yargılamanın yenilenmesine karar verildiği tarihten usul işlemleri tamamlanarak beraat kararlarının verileceği tarihe kadar, Yüksek Adalet Divanı'nda yargılanan Cumhurbaşkanı Celal Bayar, Başbakan Adnan Menderes, bakanlar, milletvekilleri ve diğer kişiler tekrar "sanık" yani 'suç şüphesi altında bulunan kişi' ${ }^{4}$ ' konumuna getirilmiş olacaktır. Oysa 22.05.1987 tarihli ve 3374 sayılı Kanun'un 1'nci maddesinde 11.04.1990 tarihli ve 3623 sayılı Kanun'la yapılan değişiklikle hukuken itibarları iade edilmiş olan ${ }^{41}$ kişilerin otuz yıl sonra tekrar sanık konumuna getirilmeleri her şeyden önce hukuken, söz konusu kanunların lafzı ve ruhu ile bağdaşmayacaktır. Daha önemlisi, Yassıada'da yargılama işlemlerine maruz bırakılan Devlet yetkililerinin uzun zaman sonra hukuken tekrar 'suç şüphesi altındaki kişi' şeklinde işlem görmeleri, bu kişilerin yakınlarının yaşadıkları acıların altmış y1l sonra tazelenmesi anlamına gelecektir ki bunun, kanun koyucunun siyaseten istemeyeceği bir durum olduğu hususunda tereddüt bulunmamaktadır.

Yukarıda değinilen noktalar bir bütün olarak ele alındığında, kanun koyucunun 7248 sayılı Kanun kapsamında Yüksek Adalet Divanı'nın hukuki dayanağını geçmişe etkili şekilde yürürlükten kaldırırken yargılamanın yenilenmesi müessesesini unutmuş veya gözden kaçırmış olmadığı; bilakis, Yüksek Adalet Divanı'nın hukuki niteliği konusunda izlediği tutarlı yaklaşımın neticesi olarak ve bilinçli şekilde yargılamanın yenilenmesi yöntemini tercih etmediği sonucuna ulaşılmaktadır.

işlenmiş, icra edilmiş ve akabinde mahkûmiyete konu olmuş bir suçun sonradan affedilmesi olduğu için, bir eylemin af kanunu kapsamına alınmasının ön koşulu onun suç teşkil ettiğinin kabul edilmesi olacaktır. Bu anlamda Yüksek Adalet Divanı kararlarına konu olan eylemler affedilmiştir anlamına gelen bir kanun, zımnen "Yüksek Adalet Divanı'nda yargılanan kişiler suç işlemişlerdir" şeklindeki olgunun kabul edildiği anlamına gelmektedir. Bu ise, 7248 sayılı Kanun ile kanun koyucunun güttüğü amaca uygun düşmemektedir.

39 Kanun teklifinde imzası olan milletvekillerinden Isparta Milletvekili Süreyya Sadi Bilgiç komisyon görüşmelerinde şunları ifade etmiştir: “... teklifle ilgili çalışmalar yapılırken yargilamanın yenilenmesi gibi bir alternatif formülün de gündeme geldiğini belirtmek isterim fakat yargllamanın yenilenmesi müessesesi, bildiğiniz gibi, bir mahkemenin ve yargılamanın varlığı yönündeki ön kabule dayanır. Dolayısıyla Yassıada kararlarını yeniden yargılamaya açmak, 2020 yılı Türkiyesi’nde Türkiye Büyük Millet Meclisinin Yüksek Adalet Divanını meşru bir mahkeme olarak kabul etmesi anlamına gelecektir. Bunu asla kabul edemeyeceğimiz için bu yöntemi benimsemedik ve Yüksek Adalet Divanını kuran hukuk metni olan 6'ncı maddeyi geçmişe dönük olarak ilga etmenin daha isabetli olacağına kanaat getirdik." bkz. https://www.tbmm.gov.tr/develop/owa/komisyon_tutanaklari. goruntule?pTutanakId=2543 Erişim tarihi: 16 Mayıs 2021

41 bkz. 17 Nisan 1990 Tarihli ve 20495 Sayılı Resmi Gazete. 
IIIIIIIIIII

\section{ULUSLARARASI INSAN HAKLARI HUKUKUNUN "GEÇIŞ DÖNEMİ ADALETİ” MÜESSESESİ ve 7248 SAYILI KANUN}

Erkler ayrılığı prensibi ile Anayasa'nın 138'inci maddesinden hareketle 7248 sayılı Kanun'a yöneltilen "açıkça hukuka aykırı nitelikte olsalar dahi mahkeme kararlarının sonradan çıkarılan kanunlarla geçmişe etkili olarak hükümsüz hâle getirilemeyeceği" eleştirisi değerlendirilirken, kanunun hukuki sonuçlarını telafi etmek istediği dönemin özellikleri dikkate alınarak, uluslararası insan hakları hukuku disiplininde yeni gelişmekte olan geçiş dönemi adaleti kurumunun da göz önünde bulundurulması faydalı olacaktır. $\mathrm{Bu}$ çerçevede her ne kadar 7248 sayılı Kanun'un teklif metninde ya da Komisyondaki ve Genel Kuruldaki görüşmelerinde geçiş dönemi adaleti kavramına yapılan hiçbir atıf bulunmasa da, anılan kanunun "27 Mayıs 1960 askerî darbesinden sonra Anayasanin ve olağan hukuk düzeninin tamamen asklya alındı̆̆ $\mathrm{l}$ ve insan haklart ihlallerinin yoğun ve ciddi olarak yaşandiğ bir dönemde vuku bulan hak ihlallerini telafi etmeye ve etkilerini azaltmaya" yönelik fonksiyonu, kanımızca onu geçiş dönemi adaleti kurumu ile ilintili hale getirmektedir.

Zira 7248 sayılı Kanun'un yukarıda aktarılan işlevi, uluslararası insan hakları hukukunda "geçiş dönemi adaleti (transitional justice)" olarak isimlendirilen, insan hakları ihlallerinin yoğun ve ciddi olarak yaşandığı dönemlerden sonra kurulan hukuk düzeni içerisinde söz konusu ihlallerin telafi edilmesini veya etkilerinin azaltılmasını amaçlayan ${ }^{42}$ müessesenin işlevi ile bir ölçüde benzerlik göstermektedir. Geçiş dönemi adaleti, genel anlamda toplumların baskıcı ve otoriter rejimlerden hukuk devletlerine geçişleri aşamasında ortaya çıkan bir olgudur ${ }^{43}$. Birleşmiş Milletlere (BM) göre geçiş dönemi adaleti, hesap verilebilirlik sağlamayı, adalet sunmayı ve uzlaşmayı amaçlayan bir toplumun, geçmişteki büyük ölçekli ihlallerin getirdiği mirasla yüzleşme girişimleriyle bağlantılı olan çok çeşitli süreç ve mekanizmalardan oluşmaktadır ${ }^{44}$.

Uluslararası Geçiş Dönemi Adaleti Merkezi geçiş dönemi adaletini sistematik ve yaygın insan hakları ihlallerine tepki olarak tanımlamakta, esas olarak amacın mağdurların tanınması, ihlallerin kabul edilmesi ve giderilmesi

42 Bkz. Pablo de Greiff, "Theorizing Transitional Justice", Melissa S. Williams, Rosemary Nagy ve Jon Elster (editörler), Transitional Justice (içinde), (1. Bası, New York Üniversitesi Yayınevi 2012) 34; Birleşmiş Milletler Güvenlik Konseyi, Genel Sekreteri Raporu, Çatışma ve Çatışma Dönemi Sonrası Toplumlarında Geçiş Dönemi Adaleti ve Hukukun Üstünlüğü, 23.08.2004, BM Doküman No:S/2004/616, prg.8

43 Jeremy Webber, "Forms of Transitional Justice", Melissa S. Williams, Rosemary Nagy ve Jon Elster (editörler), Transitional Justice (içinde), (1. Bası, New York Üniversitesi Yayınevi 2012) 98.

44 Birleşmiş Milletler Güvenlik Konseyi, Genel Sekreter Raporu, BM Doküman No:S/2004/616, s. 8 . 
ile benzer ihlallerin tekrarının engellenmesi olduğunu belirtmektedir ${ }^{45}$. BM Özel Raportörü de Greiff, geçiş dönemi adaletinde hedefleri dolaylı ve nihai hedefler olmak üzere iki başlık altında incelemekte; mağdurların tanınması ile vatandaşların güveninin sağlanması hususlarını müessesenin dolaylı hedefleri olarak gösterirken, uzlaşma ve demokratikleşmenin ise nihai hedefler olduğunu ifade etmektedir ${ }^{46}$. Bu bağlamda geçiş dönemi adaleti ile mağdurların onurlarını yeniden kazanmalarının ve toplumun aktif üyeleri olabilmelerinin amaçlandığ 1 söylenebilecektir ${ }^{47}$.

Geçiş dönemi adaleti önlemleri ile bireylerin eşit haklara sahip vatandaşlar olarak tanınmalarına yönelik kurumsal çabalar gündeme gelmektedir. $\mathrm{Bu}$ noktada temel olarak geçiş dönemi adaletine ilişkin yargisal mekanizmaların ulusal ve uluslararası mahkemeler; onarıcı mekanizmaların ise hakikat komisyonları, maddi ve sembolik tazminatlar, sorumlu kişilerin görevden uzaklaştırılması, devletin yarg1, asker ve polis mekanizmalarında reforma gidilmesi şeklinde sıralanması mümkündür ${ }^{48}$. Müesseseye yönelik ana yaklaşımlar mağdurlar, vatandaşlar ve kurumlar arasında güven inşa etmek gibi ileriye dönük önemli amaçlara yönelmişken, bunun yanında müessesenin parçası olan mekanizmalar geçmişte işlenen ihlallerin hesap verilebilirliği ile de ilgilidir ${ }^{49}$.

İnsan hakları ihlallerinin yoğun ve hatta sistematik olarak yaşandığ1 dönemlerde gerçekleştirilen adil olmayan yargılamalar sonucunda kişiler hakkında verilen mahkûmiyet kararlarının hukuka aykırı olduklarının ilanı, hukuki etkilerinin ortadan kaldırılması veya telafisi de geçiş dönemi adaleti kapsamında başvurulan tedbirlerden birisidir $^{50}$. Örneğin yakın zamanda İspanya'da, Franco döneminde bazı siyasetçiler hakkında yürütülen yargılamaların iptali sonucunu doğuracak yasama teklifleri verilmiştir ${ }^{51}$. Diğer

45 ICTJ, What is Transitional Justice, 2008.

46 Bkz. Pablo de Greiff, s.48.

47 Hunter Kolon, “A Legacy of Violence: The Lack of Transitional Justice in Post- Franco Spain and Its Impact on Victimhood", 6 (2021), SMU Journal of Undergraduate Research, 8.

48 Gülayşe Ülgen Türedi, “AB ve Geçiş Dönemi Adaleti”, II. Avrupa Birliği Hukukunda Güncel Gelişmeler Konferansı Bildiri Kitapçı̆̆ı, Ankara Üniversitesi Avrupa Toplulukları Araştırma ve Uygulama Merkezi ATAUM, 10 Mayıs 2018, s.23.

49 Eric Sottas, "Transitional Justice and Sanctions", (2008) 90 (870), International Review of The Red Cross, 377.

50 Birleşmiş Milletler İnsan Hakları Konseyi, Özel Raportör Pablo de Greiff'in İspanya Misyonu Raporu, 22.07.2014, BM Döküman No: A/HRC/27/56/Add.1, prg.94-99; Paloma Aguilar, Transitional or Post-transitional Justice? Recent Developments in the Spanish Case, South European Society and Politics, C: 13, S:4, 2008, s.426.

51 Filipa Alves Raimundo, Post-Transitional Justice? Spain - Poland and Portugal Compared, European University Institute, Siyasal ve Sosyal Bilimler Bölümü'ne sunulan doktora tezi, s.109-110. https://www.researchgate.net/ publication/287782077_PostTransitional_Justice_ Spain_Poland_and_Portugal_compared 
IIIIIIIIII!

taraftan BM İnsan Hakları Konseyi İspanya Misyonu Raporunda, iç savaş ve Franco döneminde verilen mahkeme kararlarının iptaline ilişkin yapılan değerlendirmelerde, iç savaş sırasında siyasi yahut ideolojik nedenlerle verilen hükümlerin adaletsizliği ile hukuka aykırılığını tanıyan 52/2007 sayılı Kanun'un ${ }^{52}$ memnuniyetle karşılandığ 1 ; bu yolla yalnızca sembolik tazminatları öngören düzenlemeler yerine hükümlerin hukuki sonuçlarının kaldırılmasının sağlanacăğ; hukuki belirlilik, kesin hüküm ve geriye yürümezlik ilkelerinin bu gibi düzenlemeler bakımından zorluk teşkil etmesi karşısında mahkeme kararlarının iptal edilmesi olasılığının konu dışı bırakılması yerine ayrıntılı bir biçimde değerlendirilmesi suretiyle alternatiflerin düşünülmesi gerektiği hususları belirtilmiştir ${ }^{53}$.

$\mathrm{Bu}$ noktada yargı kararlarının doğrudan yasama tasarrufu ile iptalini öngören yahut yargı kararı olarak nitelendirilen kararları gayrı meşru ilan eden ve uluslararası düzeyde memnuniyetle karşılanan yasal düzenlemelere kıyasla, geçiş dönemi adaleti kapsamında 7248 sayılı Kanun ile benimsenen yöntemin daha kabul edilebilir olduğu ileri sürülebilecektir. Zira 7248 sayılı Kanun, Yüksek Adalet Divanı kararlarını açıkça iptal ederek veya bunları hukuka aykırı ilan ederek şeklen de olsa yargı erki alanına müdahale ettiği görüntüsü vermekten kaçınmış ${ }^{54}$; sadece tersine bir yasama tasarrufu ile yürürlükteki ${ }^{55}$ bir kanun hükmünü yürürlükten kaldırmışt1 ${ }^{56}$.

52 Örneğin 26.12.2007 tarihli ve 52/2007 sayıl1 İspanya Tarihi Hafiza Kanunu'nun 3'üncü maddesi İspanya' da sivil savaş dönemine ilişkin olarak şu hükmü içermektedir: "Mahkemeler, jüriler ve sivil savaş süresince politik, ideolojik veya dini nedenlerle kişisel mahkûmiyetler veya yaptırımlar uygulamak üzere kurulan diğer tüm cezai veya idari organlar ile yine aynı şekilde bunların vermiş oldukları kararlar gayrımeşru ilan edilmektedir." bkz. http:// learning-from-history.de/sites/default/files/book/attach/ley-de-la-memoria-historica.pdf ve https://reparations.qub.ac.uk/assets/uploads/Ley-52-2007-Spain-EN.pdf Erişim tarihi: 24 May1s 2021

53 Birleşmiş Milletler İnsan Hakları Konseyi, Özel Raportör Pablo de Greiff'in İspanya Misyonu Raporu, prg.94-99.

54 Bu husus üzerinde kanun görüşmeleri esnasında da değinilmiştir. Teklif sahiplerinden Isparta Milletvekili Süreyya Sadi Bilgiç Anayasa Komisyonu'nda şu hususları ifade etmiştir: “... burada üzerinde hassasiyetle durduğumuz konuların başında yargı tasarrufunun doğrudan bir yasama tasarrufuyla iptal edilmesi anlamına gelecek bir işlemden kaçınmak gelmektedir. Ĕger buna dikkat etmez isek gerçekten de hem erkler ayrllı̆̆ prensibini açık şekilde ihlal etmiş oluruz hem de gelecekte benzer tasarruflara emsal olabilecek bir işlem tesis etmis oluruz. Bu hassasiyetle, teklifle Yüksek Adalet Divanının kararlarının hukuk dünyasındaki etkilerinin silinmesi için bu Divanı kuran kanunun geriye etkili şekilde kaldırılması formülü benimsenmiştir.” TBMM Anayasa Komisyonu Tutanak Dergisi, D. 27, Y.3, 17/6/2020.

551 sayılı Kanun'un 6'nc1 maddesinin 7248 sayılı Kanun'un TBMM'de kabul edildiği tarihte yürürlükte olduğuna ilişkin açıklamalar hakkında bkz. Şentop, agm.

56 Kanımızca kanun koyucunun burada izlediği mantık, İdare Hukuku'nda var olan, kıyasen Anayasa Hukuku'nda da uygulama alanı bulacağı değerlendirilen, "bir işlemi yapmaya yetkili olan makam o işlemi kaldırmaya, geri almaya, değiştirmeye, iptal etmeye de yetkili 
Sonuç olarak 7248 sayılı Kanun değerlendirilirken, bu kanunun yürürlükten kaldırdığı 1 sayılı Kanun'un kabul edildiği ve Yüksek Adalet Divanı'nın kurulup faaliyetlerini yürüttüğü dönemin kendine özgü koşullarının göz önünde bulundurulması gerekmektedir. Bu çerçevede 27 Mayıs 1960 askerî darbesi ile birlikte başlayıp TBMM'nin tekrar toplanmasına kadar geçen süre içerisinde yaşanılan dönemde olağan hukuk kurum ve kuralları askıya alınmış, bir kısmına yukarıda "Kanun Koyucu Yüksek Adalet Divanını Mahkeme Olarak Kabul Etmemekte Haklı Kabul Edilebilir Mi?" başlığı altında değinilen, aralarında işkencelerin ${ }^{57}$ ve yaşama hakkının ortadan kaldırılmasının da bulunduğu ağır insan hakları ihlalleri yaşanmıştır. İşte 7248 sayılı Kanun da, olağan hukuk düzeni yerleştikten sonra söz konusu olağanüstü dönemle yüzleşilmesini ve bu dönemin neden olduğu mağduriyetlerin telafi edilmesini amaçlayan bir yasal tedbir olarak, kanımızca geçiş dönemi adaleti kurumunun kapsamı içerisinde değerlendirilebilecektir. Bu noktada kanun koyucunun yasama çalışmaları esnasında uluslararası insan hakları hukukuna ya da geçiş dönemi adaleti kurumuna atıf yapmamış olması bu neticeyi değiştirmeyecektir. Dolayısıyla 7248 sayılı Kanun'un, mukayeseli hukukta uygulama alanı bulan ve uluslararası insan hakları hukukunda erkler ayrıllğı prensibine -kural olarakaykırı kabul edilmeyen bir eğilimin örneği olarak nitelendirilmesi mümkündür.

\section{E. 7248 SAYILI KANUN DARBELER ARASINDA AYRIM MI YAPTI?}

7248 sayılı Kanun şeklinde yasalaşan teklifin TBMM'deki görüşmeleri esnasında dile getirilen önemli eleştirilerden birisi, söz konusu kanun teklifinin 27 Mayıs 1960 askerî darbesinden sonra kurulan Yüksek Adalet Divanı'nın kararlarını hukuki dayanaktan yoksun hale getirmekle birlikte, diğer askerî darbelerden veya önemli toplumsal olaylardan sonra yürütülen hakkaniyete aykırı diğer yargılamalar sonucunda verilen kararları kapsamına almamasıdır. Bu noktadan hareketle 7248 sayılı Kanun'a ilişkin teklif, darbeler arasında

olduğu" prensibine (yetkide paralellik ilkesine) dayanmaktadır. Bu anlamda yasama organı eğer bir mahkeme/divan/kurul oluşturmaya ve buna bazı yargısal yetkiler vermeye yetkili ise, o halde yasama organı onu kaldırmaya da yetkilidir. İlaveten, bir mahkeme/divan/kurulu kurarken buna ilişkin yasama tasarrufunun yürürlük tarihini belirlemeye yetkili olan yasama organı, kurduğu yapıyı kaldıran tasarrufunun da yürürlük tarihini belirlemeye aynı şekilde yetkilidir. Bu veriler ışığında 7248 sayılı Kanun'un temeli, Yüksek Adalet Divanı'nı 12 Haziran 1960 tarihinde (27 Mayıs 1960'tan geçerli olacak şekilde) geçmişe etkili biçimde kuran 1 sayılı Kanun'un 6'ncı maddesinin, yine aynı tarihten yani 27 May1s 1960'dan geçerli olacak şekilde yürürlükten kaldırılmasıdır.

57 Örnek olarak bkz. "İşte Menderes'e işkencenin belgeleri”, Haber7, 13.04.2015. https:// www.haber7.com/guncel/haber/1344109-iste-menderese-iskencenin-belgeleri Erişim tarihi:25 May1s 2021; Mithat Perin, Yasslada Faciası, 27 Mayls Darbesinden Idamlara Kadar İşkence Altında Ezilenlerin Dramı, (Cilt 1, 1. Bası, Dem Basım Yayım 1990) 47, 61, 62, 170, 171, 184, 185, 241, 265. 
IIIIIIIIIII

seçici davranmakla ve darbelerden doğan mağduriyetler arasında ayrım yapmakla eleştirilmiştirir ${ }^{58}$.

Esasen kamusal önemi bulunan mesele ve olaylardan bazılarını yasama faaliyeti kapsamına alırken bazılarını almamak, yasa koyucunun takdirinde olan ve Anayasa'nın 10'uncu maddesinde öngörülen eşitlik ilkesi ihlal edilmediği sürece hukukun değil, siyaset biliminin inceleme alanına giren bir konudur. Ancak söz konusu eleştirinin temelini oluşturan tercih kanımızca 7248 sayılı Kanun'un kabulünde kanun koyucunun seçtiği ve önceki başlıklarda üzerinde durmaya çalıştı̆̆ımız yöntemle, yani Yüksek Adalet Divanı'nı kuran ve ona yargılama yetkisi veren hukuki normun geçmişe etkili şekilde yürürlükten kaldırılması metoduyla yakın ilişki içerisinde bulunduğundan, çalışma kapsamında anılan eleştiriye de değinilmesine ihtiyaç duyulmuştur.

Gerçekten 27 Mayıs 1960 askerî darbesi, Türkiye Cumhuriyeti Devleti'nde demokrasiyi kesintiye uğratan ilk silahlı eylem olmakla birlikte bu yöndeki tek eylem değildir. Bu çerçevede gerek diğer askerî darbelerden, gerekse toplumsal önemi bulunan kimi hadiselerden sonra ülkemizde yürütülen bir takım yargılamaların, adil, hakkaniyetli ve hukuka uygun olmamaları sebebiyle toplum vicdanında ciddi rahatsızlıklar uyandırdığı bilinmektedir. Ancak söz konusu yargılamalarla Yüksek Adalet Divanı yargılamalarını birbirlerinden ayıran iki önemli özellik bulunmaktadır. Ayrıca "karar merciinin geriye dönük şekilde, kurulduğu tarihten itibaren hukuk dünyasından kaldirllması" formülünün Yüksek Adalet Divanı yargılamaları açısından uygulanabilmesi de söz konusu iki özellik sayesinde mümkün olmuştur. Buna göre;i. Yüksek Adalet Divanı askerî bir darbe sonrasında, bizzat darbeyi gerçekleştirilenlerce kurulan bir karar organıdır. Yukarıda "Kanun Koyucu Yüksek Adalet Divanını Mahkeme Olarak Kabul Etmemekte Haklı Kabul Edilebilir Mi?" başlığı altında da belirtildiği üzere, Yüksek Adalet Divanı'nın kuruluşu ile egemenliğin sahibi olan millet arasında hiçbir rabıta yoktur. Bu nedenle Yüksek Adalet Divanı, varlığına ve faaliyetlerine meşruiyet sağlayacak herhangi bir dayanağa sahip değildir.

ii. Yüksek Adalet Divanı açısından gündeme gelen hukuka aykırılıklar bu divanın varlığına ve dolayısıyla istisnasız tüm kararlarına sâridir. Bu çerçevede örneğin Yüksek Adalet Divanı'nın, doğal hâkim ilkesine aykırı olmayan

58 bkz. 218 sıra sayılı Anayasa Komisyonu Raporu ve Rapora yazılan ek görüş ile muhalefet şerhi. 1924 Tarih ve 491 Sayılı Teşkilatı Esasiye Kanununun Bazı Hükümlerinin Kaldırılması ve Bazı Hükümlerinin Değiştirilmesi Hakkında Geçici Kanunun Bazı Maddelerinin Yürürlükten Kaldırllması ve Neden Olunan Mağduriyetlerin Giderilmesi Hakkında Kanun Teklifi (2/2952) ve Anayasa Komisyonu Raporu, Sira Sayıs1: 218 (D.27, Y.3, B.103, 23/6/2020'ye eklidir). https://www.tbmm.gov.tr/sirasayi/donem27/yil01/ss218.pdf Erişim tarihi: 20 Mayıs 2021 
tek bir kararı dahi yoktur. Bunun bir uzantısı olarak, Yüksek Adalet Divanı kararlarının tamamının geçmişe etkili şekilde hükümsüz kılınması sebebiyle kamu düzenin bozulması veya kişilerin kazanılmış haklarının zedelenmesi gibi bir ihtimalin açığa çıkması söz konusu değildir. Dolayısıyla bu olgu, Yüksek Adalet Divanı'nın geçmişe etkili şekilde hukuk âleminden kaldırılmasını hukuk devleti ilkesine aykırı olarak nitelendirmemeyi ${ }^{59}$ mümkün kılan temel faktördür.

Bu noktada 7248 sayılı Kanun'un askerî darbeler ve hakkaniyete aykırı yargılamalar arasında ayrımcılık yaptığı yönündeki eleştiriler dile getirilirken verilen örneklerden istiklal mahkemeleri ${ }^{60}$, TBMM'nin 18.09.1920 tarihli ve 45 sayılı kararıyla kurulmuştur ${ }^{61}$. Yine 12 Mart 1971 tarihli askerî muhtıra ile 12 Eylül 1980 tarihli askerî darbeden sonra gerçekleşen tartışmalı yargılamaları yürüten s1kıyönetim mahkemeleri' ${ }^{2}, 22.05 .1940$ tarihli ve 3832 sayılı Örfi İdare Kanunu ile bu kanunu ilga eden 13.05.1971 tarihli ve 1402 sayılı Kanun'a göre yetki kullanmıştır ${ }^{63}$. Benzer şekilde Devlet Güvenlik Mahkemeleri ${ }^{64}$ de

59 Bkz. Şentop, agm, s.122-124.

60 “... İstiklal mahkemelerini -tabii ‘birinci dönem' 'ikinci dönem' ‘üçüncü dönem' şeklinde, farklı konulara ilişkin her ne kadar farklı dönemlere ayrılmışsa da genel itibarıyla bahsettiğimiz üzere, hukuka aykırı, antidemokratik infaz kurulları olarak gördüğümüzü belirtmek isteriz. Yine, istiklal mahkemelerinin en temel karakteri yargılananların itiraz yani temyiz hakkının bulunmamasıdır. Aslında, bu bile, 1960'daki yapılan yargılama diyemeyeceğiz ismine, hani infaz kurulunun yaptığının aynısı burada da başlı başına vardı, o dönemde de vardı." Şırnak Milletvekili Hüseyin Kaçmaz'ın teklifin Anayasa Komisyonu'ndaki görüşmeleri esnasında yaptığı açıklamalardan alınmıştır. bkz. TBMM Anayasa Komisyonu Tutanak Dergisi, D:27, Y:3, 17/6/2020.

61 Ístiklal Mahkemeleri, Kanun, Gerekçe ve Genel Kurul Tutanakları, İstiklal Mahkemeleri, Kanun, Gerekçe ve Genel Kurul Tutanakları, (Cilt I, TBMM Yayınları 2015) 9,10.

62 "27 Mayıs 1960 Askerî Darbesi, 12 Mart 1971 Askerî Muhtırası ve 12 Eylül 1980 Askerî Darbesi Dönemlerinde Askerî ve Sikıyönetim Mahkemelerince Yapılan Yargılamaların Hükümsüz Kılınması ve Yol açılan Mağduriyetlerin Giderilmesine Dair Kanun Teklifi ... 12 Mart 1971 muhtırasindan sonra görev yapan sıklyönetim askerî mahkemeleri de binlerce vatandaşımızı sadece siyasi görüşlerinden dolayı özgürlüklerinden mahrum bırakmış; Deniz Gezmiş, Yusuf Aslan ve Hüseyin İnan'ı ölümle cezalandirmış ve bu cezalar bugün hepimize utanç veren bir öç alma duygusuyla hareket edilerek yapılmıştır. Yine, 12 Eylül 1980 askerî darbesi döneminde görev yapan sılkyönetim askerî mahkemeleri de yine siyasi suçlamalarla binlerce vatandaşımızı özgürlüklerinden yoksun birakılmalarına ve ölüm cezasıyla cezalandırllmalarına karar vermiştir. Yargılanmalar sırasında yapılan bütün işkencelere de göz yumulmuştur." 7248 sayılı Kanun'a ilişkin teklifin Anayasa Komisyonu'ndaki görüşmeleri esnasında İstanbul Milletvekili İbrahim Özden Kaboğlu ile 5 milletvekili tarafından verilen değişiklik önergesinin başlığ ve gerekçesinden alınmıştır. bkz. TBMM Anayasa Komisyonu Tutanak Dergisi, D:27, Y:3, 17/6/2020.

63 bkz. 25 Mayıs 1940 Tarihli ve 4518 Sayılı Resmi Gazete, 15 May1s 1971 Tarihli ve 13837 Sayılı Resmi Gazete.

64 “... Evet, 28 Şubat sürecini de sorgulamak zorundayız. Ben yaşadım, ben o insanların durumunu gördüm. Başını açmak zorunda kalan insanlar vardı. O zaman da çok ciddi 
IIIIIIIIII!

1961 Anayasası'nın 136'ncı maddesinde 1973 yılında yapılan değişiklikle, "Devletin ülkesi ve milletiyle bütünlügü, hür demokratik düzen ve nitelikleri Anayasada belirtilen Cumhuriyet aleyhine işlenen ve doğrudan doğruya Devlet güvenliğini ilgilendiren suçlara bakmakla görevli" olmak üzere kurulmuştur ${ }^{65}$.

Dolayısıyla 7248 sayılı Kanun'a ilişkin teklife yöneltilen eleştirilerde örnek verilen ve hakkaniyete aykırı yargılamalar yürüttüğünden bahisle kararlarının geçersiz sayılması istenilen diğer merciler, "egemenlik kayıtsız şartsız milletindir" prensibine uygun şekilde TBMM tarafından alınan bir karar yahut kabul edilen bir kanunla hukuk dünyasında varlık kazanmış olan mahkemelerdir. Bu mahkemeler, yargılama usullerinde ve kararlarında bir takım hukuka aykırılıklar bulunmakla birlikte, belirli eylemlerin icrasından sonra münhasıran bu eylemleri ve ismen belli sınırlı sayıdaki kişileri yargılamak üzere kurulmuş merciler değildir. Bu nedenle sadece eski Cumhurbaşkanı, Başbakan, bakanlar ile Demokrat Parti mensuplarını yargılamak üzere kurulmuş olan ve bu yargılamalar dışında başka hiçbir yargısal faaliyeti bulunmayan Yüksek Adalet Divanı'nın bire bir benzeri olan başka bir merciin Türk Hukuku'nda bulunmadığını belirtmek yanlış olmayacaktır66.

bir hukuksuzluk vard, devlet güvenlik mahkemeleri vardl, okuldan atılan insanlar okula dönemiyordu. Gerçekten biz bunlardan ciddi anlamda mustarip olduk. Hepsini sorgulamak zorundayız. Yani Türkiye son altmış yılda gerçekten çok zor şeyler yaşadı. O yüzden, bunların da hakkını teslim etmek zorundayız. ..." Mersin Milletvekili Ali Mahir Başarır'ın, teklifin Anayasa Komisyonu'ndaki görüşmeleri esnasında yaptığı açıklamalardan, bkz. TBMM Anayasa Komisyonu Tutanak Dergisi, D:27, Y:3, 17/6/2020.

65 bkz. 20 Mart 1973 Tarihli ve 14482 Sayılı Resmi Gazete.

${ }^{66}$ Komisyon görüşmelerinde bu noktaya şu şekilde işaret edilmiştir: "Bu kanun teklifi kamuoyunda ilk gündeme geldiğinde gerek Deniz Gezmiş ve arkadaşları hakkındaki yargllamaların gerek 1980 darbesinden sonra sikıyönetim mahkemelerinde ve DGM'lerde yapılan yargılamaların haksızlığından bahisle kamuoyunda bir tartışma başlatılmıştır. Bu çerçevede "Ĕ̆er Yassiada kararları için bir girişim başlatıliyorsa neden mesela 12 Martta veya 12 Eylüldeki idamlar veya mağduriyetler için de bir adım atılmıyor?" gibi değerlendirmeler yapıldığını da gördük. Kanımızca, bu zikrettiğimiz mahkemeler ve burada yapılan yargılamalar ile Yassıada'da Yüksek Adalet Divanındaki yargılamalar arasında yapılacak bir kıyas doğru olmayacaktır. Öncelikle bu mahkemeler, sonuçlarını beğensek de beğenmesek de Yassıada mahkemesi gibi doğal hâkim ilkesine aykırı bir şekilde sadece belirli kişileri yargılamak üzere kurulmuş mahkemeler değillerdir. İkinci olarak, bu mahkemelerin hiçbiri, Yassıada'da olduğu gibi yargılamaya konu eylemlerin gerçekleştiği tarihten sonra kurulmamışlardır. Üçüncü ve son olarak da bu mahkemeler, kendi dönemlerinin anayasasına ve meri mevzuatına uygun olarak kurulmuşlardır. Diğer bir ifadeyle, Türkiye Cumhuriyeti devletinin kuruluş felsefesi ve değişmez anayasal prensibi olan "Egemenlik kayıtsız şartsız milletindir" ilkesine uygun şekilde, bu mahkemelerin kuruluşu ya Anayasa 'ya ya da milletin temsilcisi olan Meclis tarafindan ihdas edilen kanunlara, özetle de milletten alınan bir yetkiye dayanmıştır. Yüksek Adalet Divanı adı verilen bu sözde mahkeme ise bu temel nitelikten de mahrumdur." Teklif sahiplerinden Isparta Milletvekili Süreyya Sadi Bilgiç'in komisyondaki açıklamalarından alınmıştır. bkz. TBMM Anayasa Komisyonu Tutanak Dergisi, D:27, Y:3, $17 / 6 / 2020$. 
Yine bu noktanın uzantısı olarak, Yüksek Adalet Divanı açısından dile getirilen ağır hukuksuzlukların bu divanın bazı işlemleri için değil istisnasız tüm tasarrufları için geçerli olması, Yüksek Adalet Divanı kararlarının hukuk dünyasındaki etkilerinin silinebilmesi için "divanı kuran kanunun geriye etkili şsekilde yürürlükten kaldırlması" formülünü hukuken uygulanabilir kılmıştır. Oysa yukarıda yer verilen ve Yüksek Adalet Divanı ile kıyaslanan diğer örneklerin her birinde, yargılamaları yapan mahkemelerin eleştiri konusu edilenlerden başka hukuka ve hakkaniyete uygun yargılamalar yapmış olmaları ihtimal dâhilindedir ${ }^{67}$. $\mathrm{Bu}$ nedenle onlar hakkında "mahkemeyi kuran kanunun geriye etkili şekilde yürürlükten kaldırllması" formülünün uygulanabilmesi mümkün değildir. Zira bu durumda anılan mahkemelerin hukuka ve hakkaniyete uygun olan, işlenmiş bir suç sebebiyle bozulan kamu düzeninin tesisi için yürürlükteki mevzuat kurallarına uygun şekilde verdikleri kararlar da hükümsüz hale gelecek ve içinden çıkılması oldukça zor, hukuki bir kaosla karşılaşılacaktır.

Elbette Yüksek Adalet Divanı ile aralarında var olan bu farklılıklar, istiklal mahkemeleri, sıkıyönetim mahkemeleri ve devlet güvenlik mahkemelerinin yürüttüğü adil olmayan, hukuka ve hakkaniyete aykırı yargılamalardan kaynaklanan mağduriyetlerin telafi edilmesine engel değildir. Ancak bu başl1k altında değinilen farklılıklar, 7248 sayılı Kanun'la Yüksek Adalet Divanı için benimsenen "karar merciinin geçmişe dönük şekilde yürürlükten kaldırılması", formülünün istiklal mahkemeleri, sıkıyönetim mahkemeleri ve devlet güvenlik mahkemeleri açısından uygulanmasını imkânsız kılmaktadır. Bununla birlikte anılan mercilerin hukuka aykırı yargılamalarından kaynaklanan mağduriyetlerin kanun koyucu tarafından farklı yöntemlerle telafi edilmesi şüphesiz her zaman için mümkün bulunmaktadır.

\section{SONUÇ}

Türkiye'de 27 Mayıs 1960 tarihinde gerçekleştirilen askerî darbeden sonra, darbenin faili olan Milli Birlik Komitesi tarafından çıkarılan 12 Haziran 1960 tarihli ve 1 sayılı Kanun'la, münhasıran eski Cumhurbaşkanını, Başbakanı, bakanları, iktidar partisi milletvekillerini ve bunların suçlarına iştirak edenleri soruşturmak ve yargılamak üzere Yüksek Soruşturma Kurulu ile Yüksek Adalet Divanı kurulmuştur. Ayrıca 14 Haziran 1960 tarihli Resmi Gazete'de yayımlanan söz konusu kanunun yürürlük tarihi 27 Mayıs 1960 olarak

${ }^{67}$ En azından yüzlerce ve hatta binlerce karar veren bu mercilerin verdiği kararların tamamı tüketici bir yöntemle ele alınıp incelenmeden, anılan mercilerin verdikleri kararların tamamının evrensel hukuk prensiplerine aykırıllğı ileri sürülemeyecektir. Örneğin İstiklal Mahkemeleri, eleştiri konusu yapılan siyasi yönü ağır basan eylemlerin yanı sıra başta askerlikten firar suçu olmak üzere, gasp, soygun, iç güvenliği ihlal, bozgunculuk ve casusluk gibi o dönemde kamu düzenini ciddi şekilde bozan ve doğal hakim ilkesine ya da kanunilik ilkesine aykırılık arz etmeyen suçları da yargılamıştır. İstiklal Mahkemeleri, s.10. 
IIIIIIIIII!

belirlenerek, bu kurulların varlığına ve yetki kullanmalarına dayanak oluşturan normların geçmişe yürümesi sağlanmıştır.

27 Mayıs 1960 askerî darbesinin gerçekleşmesinden tam altmış yıl sonra, 23 Haziran 2020 tarihinde TBMM'de kabul edilen 7248 sayılı Kanun ise, 12.06.1960 tarihli ve 1 sayılı Kanun'un Yüksek Adalet Divanı ile Yüksek Soruşturma Kurulu'nu kuran 6'ncı maddesini 27 Mayıs 1960 tarihinden geçerli olacak şekilde yürürlükten kaldırmıştır. 7248 sayılı Kanun'a ilişkin teklif metni ile teklifin TBMM'deki görüşmelerinden, söz konusu kanunla Yüksek Adalet Divanı tarafindan verilen kararların hukuki mevcudiyetlerine son verilmesinin ve böylece anılan divan tarafından suçlu bulunan şahısların Türk pozitif hukukunda 'herhangi bir suçtan mahkûm olmamış' kişiler konumuna getirilmesinin amaçlandığ 1 anlaşılmaktadır.

Y1llar önce kurulup, ilgili mevzuatı uyarınca yetki kullanan ve hukuk dünyasında çeşitli sonuçlar doğuran kararlar veren bir makamın kuruluşuna ilişkin normun, geçmişe etkili şekilde kabul edildiği tarihten itibaren yürürlükten kaldırılması, hukuk tarihimizde benzerine rastlanmayan bir olgudur. $\mathrm{Bu}$ nedenle sira dişı bir kanun olarak nitelendirilebilecek olan 7248 sayılı Kanun'un yürürlüğe girmesinden sonra öğretide, anılan kanuna yönelik kayda değer eleştiriler dile getirilmiş̧ir. Bu kapsamda Yüksek Adalet Divanı tarafından verilen yargı kararlarını hükümsüz hale getirmesi sebebiyle erkler ayrılığı prensibine ve Anayasa'nın 138'inci maddesine aykırı olduğu yönündeki eleştiri, 7248 sayılı Kanun hakkında ileri sürülen eleştirilerin en dikkat çekicilerinden birini oluşturmaktadır.

Ancak 7248 sayılı Kanun'a ilişkin yasama belgeleri incelendiğinde, kanun koyucunun Yüksek Adalet Divanı'nı bir mahkeme veya yarg1 organı olarak nitelendirmediği, bu kapsamda örneğin kanunun komisyondaki görüşmeleri esnasında söz konusu divanın bilinçli şekilde ve israrla "sözde mahkeme" yahut "düzmece mahkeme" olarak anıldığı görülmektedir. Yüksek Adalet Divanı ve yürüttüğü yargılamalar açısından geçerli olan doğal hâkim ilkesine, kanunsuz suç olmaz prensibine ve masumiyet karinesine ilişkin hukuka aykırılıkların divanın sadece bazı kararlarına değil kuruluşuna, hatta varlığına ve istisnasız tüm işlemlerine sirayet ettiği dikkate alındığında; ayrıca yine kurulduğu dönemde yürürlükte olan "egemenlik kayltsız şartsız milletindir" prensibine aykırı şekilde milletle arasında hiçbir bağlantı olmamasına rağmen egemenlik yetkisi kapsamında kalan yargısal faaliyetler yürüttüğü göz önünde bulundurulduğunda; kanun koyucunun, Yüksek Adalet Divanı'nı Anayasa'nın 138'inci maddesi anlamında bir mahkeme olarak kabul etmemekte tamamen haksız sayılamayacağ düşünülmektedir. Bu çerçevede çalışmada ulaştı̆̆ımız sonuç, Yüksek Adalet Divanı'nın bir mahkeme olarak değil, yargısal yetkiler kullanan nevi şahsına münhasır (sui generis) bir kurul olarak nitelendirilmesinin daha isabetli bir yaklaşım olacağı yönündedir. 
Yüksek Adalet Divanı bir mahkeme ve kararları da yarg1 kararı olarak nitelendirilmediği takdirde, bu divanı geçmişe etkili şekilde yürürlükten kaldıran 7248 sayılı Kanun'un erkler ayrılığı prensibine ya da Anayasa'nın 138 'inci maddesinin 'yasama ve yürütme organlarını mahkeme kararların hiçbir suretle değiştiremeyeceklerine' ilişkin dördüncü fikrasına aykırılık taşımadığı belirtilebilecektir. Nitekim Yüksek Adalet Divanı kararlarını geçersiz k1lmak isterken, kanun koyucunun yöntem olarak yargılamanın yenilenmesi müessesesini tercih etmemesinin sebebi de budur. Zira yargilamanın yenilenmesinin ön koşulu bir mahkemenin ve yargı kararının varlığıdır. Dolayısıyla 7248 sayılı Kanun'da Yüksek Adalet Divanı kararları açısından yargılamanın yenilenmesinin öngörülmesi, söz konusu divanın 2020 yılında kanun koyucu tarafindan mahkeme olarak nitelendirilmesi anlamına gelecek ve ona 'mahkeme' olarak hukuki meşruiyet kazandıracaktır. Ayrıca yargılamanın yenilenmesi yöntemi, Yüksek Adalet Divanı tarafından hakkında karar verilenleri günümüzde -kaçınılmaz olarak- tekrar sanık statüsüne getirecektir. Ne var ki askerî darbe mağdurlarında ve toplum vicdanında açılmış bulunan yaraların altmış yıl sonra tazelenmesi neticesini verecek böyle bir adımın 7248 sayılı Kanun'un ulaşmak istediği amaçlarla bağdaşmayacağı açıktır.

Yüksek Adalet Divanı'nı kuran kanunu geçmişe etkili olarak yürürlükten kaldırması sebebiyle, 7248 sayılı Kanun'a yasamanın yargıya müdahalesi bağlamında erkler ayrılığı perspektifinden yöneltilen eleştiriler değerlendirilirken, uluslararası insan hakları hukukunun yeni gelişmekte olan geçiş dönemi adaleti kurumu da göz önünde bulundurulmalıdır. Her ne kadar teklif metninde ve 7248 sayılı Kanun'un yasalaşması sürecinde TBMM'de yapılan görüşmelerde geçiş dönemi adaletinden hiçbir şekilde söz edilmese de, insan hakları ihlallerinin yoğun şekilde yaşandığı dönemlerden sonra kurulan hukuk düzeni içerisindeki telafi edici tedbirleri inceleme konusu yapan bu müessese, kanımızca -dolaylı da olsa- 7248 sayılı Kanun ile bağlantılı görülebilecektir. Zira 27 Mayıs 1960 askerî darbesinin bizzat kendisinin, darbe sonrası yürütülen soruşturmaların ve yargılamaların içerdiği yoğun hukuka aykırılıklar ve insan hakları ihlalleri, olağan hukuk düzenine geçildikten sonra darbenin yol açtığı mağduriyetleri giderici tedbirler öngören 7248 sayılı Kanun'un teorik anlamda geçiş dönemi adaleti kapsamında değerlendirilmesini mümkün kılmaktadır. Bu çerçevede temel haklara ve hukukun genel ilkelerine aykırı yargı kararları hakkında mukayeseli hukukta alınan geçiş dönemi adaleti tedbirlerinin, bu kapsamda yargı kararlarını doğrudan gayrı meşru ilan eden kanunların dahi uluslararası insan hakları hukuku bağlamında takdirle karşılanması, kanımızca 7248 sayılı Kanun değerlendirilirken dikkate alınması gereken bir diğer faktörü oluşturmaktadır.

7248 sayılı Kanun'a yönelik eleştirilerden bu çalışma kapsamında incelenen bir diğeri, TBMM'deki yasama görüşmeleri esnasında milletvekilleri 
IIIIIIIIIII

tarafından gündeme getirilen "kanunun askerî darbelerle hakkaniyete aykırı yargılamalar arasında seçici davrandiğı ve ayrımcılık yaptığı" eleştirisidir. Ancak bu eleştiri bağlamında örnek verilen ve sonuçlarının ortadan kaldırılması istenilen yargılamalar incelendiğinde, bir takım hukuka aykırılıklar içeren bu yargılamaları icra eden mahkemelerin, (Yüksek Adalet Divanı gibi) belirli eylemlerin icrasından sonra münhasıranbueylemleriyargılamaküzerekurulmuş merciler olmadıkları ve Yüksek Adalet Divanı'ndan farklı olarak, bir kanunla veya TBMM kararıla, yani millet iradesine dayanan hukuki tasarruflarla kuruldukları görülmektedir. Daha önemlisi, Yüksek Adalet Divanı'nın aksine, bu eleştiri kapsamında örnek gösterilen mahkemelerin verdikleri kararların tamamının -istisnasız bir şekilde ve kesin olarak- hukuka aykırı olduklarının ortaya konulamamas1, onlar hakkında "mahkemeyi kuran kanunun geriye etkili şekilde yürürlükten kaldırlması" formülünün uygulanabilmesini, dolayısıyla 7248 sayılı Kanun kapsamına bu mahkemelerin de alınabilmesini imkânsız k1lmaktadır.

Son olarak, öğretide 7248 sayılı Kanun hakkında öne sürülen ve çalışma kapsamında ele alınan eleştirilerle bağlantılı bir diğer eleştiri, bu kanunun, hukuki kurumları geçmişe etkili şekilde yürürlükten kaldıracak başka yasal düzenlemelerin (gelecekte) kabulüne örnek oluşturabilecek olmas ${ }^{68}$ ve bu tür bir olası düzenlemenin hukuk devleti ilkesine aykırı sonuçlar doğurabilmesidir. Kanımızca bu eleştiri ancak 7248 sayılı Kanun'un dayanağını yürürlükten kaldırdığ1 Yüksek Adalet Divanı ile kıyası mümkün olan, onunla aynı mahiyetteki bir kurum ya da kurulun geçmişe etkili şekilde yürürlükten kaldırılması söz konusu olduğunda haklı görülebilecektir. Diğer bir ifadeyle 7248 sayılı Kanun'un gelecekte benzer bir yasal düzenlemeye örnek teşkil etmesi, ancak kendisinin ilga ettiği normla kurulan Yüksek Adalet Divanı ile aynı mahiyetteki bir başka merciin hukukumuzda varlık kazanması ihtimalinde gündeme gelebilecektir. Aksi takdirde iddia edildiği şekilde bir örnek almaya temel teşkil edecek kıyaslama, birbirinden farklı iki şeyin kıyası yani klyas-1 maal fârık mahiyetinde olacaktır. Somutlaştırmak gerekirse, 7248 sayılı Kanun gelecekte ancak,

- Milletten hiçbir yetki almayan kişi ya da kişi gruplarının egemenliği salt fiziki güce dayanarak hukuka aykırı şekilde ele geçirmeleri, Anayasa'yı ve ülkede cari olan olağan hukuk sistemini askıya almaları,

68 "Geçmişte anayasal veya yasal dayanağı olan makam ve organların dayandı̆̆ anayasa ve kanun hükümlerini gelecekte, geçmişe etkili olarak yürürlükten kaldırarak, bu makam ve organları yasa dışı hâle getirmenin yolu bir kez açılırsa ... ." Kemal Gözler, Yürürlükte Olmayan Bir Kanun Yürürlükten Kaldırılabilir Mi? “... siyaseten ve vicdanen bu Kanunda bir sakınca görülmese de, örnek olma ve 'hukuk devleti' ilkesi bakımından ciddi sakıncaların bulunduğu, ileride bunların başka yasa düzenlemelerine örnek teşkil edebileceği, ..." Şen, agm. 
- Bu kişi ya da kişi gruplarının sadece cezalandırmak istedikleri ismen belli bazı bireyleri yargılamak üzere bir makam teşkil etmeleri,

- Söz konusu yargılama makamı nezdinde bireylerin, eylem tarihinde suç olmayan fiillerinden dolayı yargılanmaları ve hüküm giymeleri,

- Bu yargılama makamı nezdinde yargılanacak kişilerin daha yargılama süreci devam ederken egemenliği fiilen ele geçiren kişilerce suçlu ilan edilmeleri,

- Yargı yetkisi kullanan söz konusu makamın, doğal hâkim ilkesine, kanunsuz suç olmaz prensibine ve masumiyet karinesine aykırı olanlar dışında başka hiçbir hukuki tasarrufunun bulunmaması,

- Yaşanan tüm bu süreçten sonra milletin egemenliğini yeniden kazanması ve millet egemenliğine dayalı olağan hukuk düzenine geçilmesi ve

- Olağan hukuk düzenine geçildikten sonra, bahsi geçen yargılama makamının hukuki varlığına geçmişe etkili şekilde son verilmesinin kazanılmış hakları olumsuz yönde etkileyen ya da kamu düzeni ve kamu yararı açısından sakınca arz eden hiçbir netice doğurmamas1

koşullarının bir arada gerçekleşmesi durumunda, egemenliği fiziki güce dayanarak ele geçirenler tarafından hukuka aykırı yargılamalar yapmak üzere kurulan makamı geçmişe etkili şekilde yürürlükten kaldıracak bir kanuna örnek teşkil edebilecektir. Bu ise kanaatimizce, Anayasa'nın ve hukukun üstünlüğü açısından bir "olumsuz örnek oluşturma" hali olarak nitelendirilemeyecektir.

\section{KAYNAKÇA}

Aguilar P, "Transitional or Post-transitional Justice? Recent Developments in the Spanish Case", South European Society and Politics, (2008) 13 (4)

Birleşmiş Milletler Güvenlik Konseyi, Genel Sekreter Raporu, Çatışma ve Çatışma Dönemi Sonrası Toplumlarında Geçiş Dönemi Adaleti ve Hukukun Üstünlüğü, 23.08.2004, BM Doküman No:S/2004/616. [ https://www.un.org/ ruleoflaw/files/2004\%20report.pdf ] (Erişim Tarihi 20 Mayıs 2021)

Birleşmiş Milletler İnsan Hakları Konseyi, Özel Raportör Pablo de Grieff'in İspanya Misyonu Raporu, 22.07.2014, BM Döküman No:A/HRC/27/56/Add.1 https://undocs.org/en/A/HRC/27/56/Add.1 (Erişim Tarihi: 18 Mayıs 2021) Birleşmiş Milletler Uluslararası Hukuk Komisyonu, Nuremberg İlkeleri, 1950 https://legal.un.org/ilc/texts/instruments/english/draft_articles/ 7_1_1950.pdf (Erişim Tarihi: 11 Mayıs 2021)

De Greiff P, 'Theorizing Transitional Justice', Melissa S. Williams, Rosemary Nagy ve Jon Elster (editörler), Transitional Justice (içinde), (1. Bası, New York Üniversitesi Yayınevi 2012) 31-77 
IIIIIIIIII!

Gözler K, "Yürürlükte Olmayan Bir Kanun Yürürlükten Kaldırılabilir Mi? 23 Haziran 2020 Tarih ve 7248 Sayılı Kanun Hakkında Eleştiriler" (Türk Anayasa Hukuku Sitesi, 25.06.2020) www.anayasa.gen.tr/7248-sayili-kanun. htm Erişim Tarihi: 06 Mayıs 2021

Gözler K, "Sulh Ceza Hâkimlikleri ve Tabiî Hâkim İlkesi: 'Sahur Operasyonu' Hakkında Bir Açıklama”, (Türk Anayasa Hukuku Sitesi, 29.08.2014) www. anayasa.gen.tr/tabii-hakim.htm Erişim Tarihi: 06 Mayıs 2021

ICTJ, What is Transitional Justice, 2008. https://www.ictj.org/about/ transitional-justice

İstiklal Mahkemeleri, Kanun, Gerekçe ve Genel Kurul Tutanakları, (Cilt I, TBMM Yayınları 2015)

Kolon H, "A Legacy of Violence: The Lack of Transitional Justice in PostFranco Spain and Its Impact on Victimhood", (2021) 6 SMU Journal of Undergraduate Research

Önder A, Ceza Hukuku Dersleri, (1. Basım, Filiz Kitabevi 1992)

Perin M, Yassıada Faciası, 27 Mayıs Darbesinden İdamlara Kadar İşkence Altında Ezilenlerin Dramı, (Cilt 1, 1. Bası, Dem Basım Yayım 1990)

Sottas E, "Transitional Justice and Sanctions" (2008) 90 (870) International Review of The Red Cross, 371-398

Şen E, “Yüksek Adalet Divanı'nı Kaldıran 7248 Sayılı Kanunun Değerlendirilmesi" (Hukuki Haber, 27.06.2020) Erişim Tarihi: 06 Mayıs 2021

Şentop M, “Bir Kanunun Tahlili: 7248 Sayılı Kanun Nedir, Ne Değildir?”(2020) (42), Yasama Dergisi 97-130

Raimundo F.A, Post-Transitional Justice? Spain - Poland and Portugal Compared, European University Institute, Siyasal ve Sosyal Bilimler Bölümü’ne sunulan doktora tezi

https://www.researchgate.net/publication/287782077_Post-Transitional_ Justice_Spain_Poland_and_Portugal_compared (Erişim Tarihi: 20 Mayıs 2021)

Tanrıvermiş A, Lekelenmeme Hakkı, (1. Bası, Seçkin Yayıncılık 2021)

TBMM Anayasa Komisyonu Tutanak Dergisi, Dönem 27, Yasama Y1lı 3, 17 Haziran 2020. https://www.tbmm.gov.tr/develop/owa/komisyon_tutanaklari. goruntule?pTutanakId=2543

TBMM Genel Kurul Tutanağı, 27. Dönem 3. Yasama Y111, 103. Birleşim, 23 Haziran 2020 
https://www.tbmm.gov.tr/develop/owa/Tutanak_B_SD.birlesim_ baslangic?P4=23465\&P5=H\&PAGE1 $=1 \&$ PAGE2 $=76$

Tomuschat C, (2006) 4 (4) The Legacy of Nuremberg, Journal of International Criminal Justice, 830-844

Toroslu N, Ceza Hukuku Genel Klsım, (20. Bası, Savaş Yayınları 2014)

Ülgen Türedi G, “AB ve Geçiş Dönemi Adaleti”, II. Avrupa Birliği Hukukunda Güncel Gelişmeler Konferansı Bildiri Kitapçı̆̆ı̆, Ankara Üniversitesi Avrupa Toplulukları Araştırma ve Uygulama Merkezi ATAUM, 10 Mayıs 2018, 23.

Webber J, 'Theorizing Transitional Justice', Melissa S. Williams, Rosemary Nagy ve Jon Elster (editörler), Transitional Justice (içinde), (1. Bası, New York Üniversitesi Yayınevi 2012) 98-128

Yassıada Broşürü, Milli Birlik Komitesi İrtibat Bürosu, , Basın Yayın ve Turizm Genel Müdürlüğü, Ekim 1960 http://menadoc.bibliothek.uni-halle.de/ landau/content/titleinfo/208980

Yurtcan E, Ceza Yargılaması Hukuku, (16. Bası, Seçkin Yayıncılık 2019)

Yüksek Adalet Divanı Kararları, İstanbul - Yassıada 14 Ekim 1960 - 15 Eylûl 1961, (1. Bas1, Kabalc1 Yayınevi 2007)

\section{Resmi Gazete}

26.12.2007 tarihli ve 52/2007 sayılı İspanya Tarihi Hafiza Kanunu http://learning-from-history.de/sites/default/files/book/attach/ley-de-lamemoria-historica.pdf;

https://reparations.qub.ac.uk/assets/uploads/Ley-52-2007-Spain-EN.pdf (Erişim Tarihi: 24 Mayıs 2021)

“İşte Menderes'e işkencenin belgeleri”, Haber7, 13.04.2015

https://www.haber7.com/guncel/haber/1344109-iste-menderese-iskenceninbelgeleri (Erişim Tarihi: 25 Mayıs 2021) 
216 